\title{
Extracellular Vesicles for the Treatment of Radiation Injuries
}

\author{
Lalitha Sarad Yamini Nanduri ${ }^{1}$, Phaneendra K. Duddempudi ${ }^{2}$, Weng-Lang Yang ${ }^{1}$, \\ Radia Tamarat ${ }^{3}$ and Chandan Guha ${ }^{1,4,5,6 *}$ \\ ${ }^{1}$ Department of Radiation Oncology, Albert Einstein College of Medicine, Montefiore Medical Center, New York, NY, \\ United States, ${ }^{2}$ Department of Biochemistry, Albert Einstein College of Medicine, Montefiore Medical Center, New York, NY, \\ United States, ${ }^{3}$ Institut de Radioprotection et de Sûreté Nucléaire (IRSN), Fontenay-aux-Roses, France, ${ }^{4}$ Department of \\ Pathology, Albert Einstein College of Medicine, Montefiore Medical Center, New York, NY, United States, ${ }^{5}$ Department of Urology, \\ Albert Einstein College of Medicine, Montefiore Medical Center, New York, NY, United States, ${ }^{6}$ Institute for Onco-Physics, Albert \\ Einstein College of Medicine, Montefiore Medical Center, New York, NY, United States
}

\section{OPEN ACCESS}

Edited by:

Diane Riccobono,

Institut de Recherche Biomédicale des Armées (IRBA), France

Reviewed by:

Shiang Y. Lim,

University of Melbourne, Australia Nicola Alessio,

Università della Campania Luigi Vanvitelli, Italy

Ramon Lopez Perez,

German Cancer Research Center (DKFZ), Germany

Umberto Galderisi,

University of Campania Luigi Vanvitelli,

Italy

*Correspondence:

Chandan Guha

cguhamd@gmail.com

Specialty section:

This article was submitted to Translational Pharmacology, a section of the journal Frontiers in Pharmacology

Received: 01 February 2021 Accepted: 04 May 2021

Published: 18 May 2021

Citation:

Nanduri LSY, Duddempudi PK, Yang $W$-L, Tamarat $R$ and Guha $C$ (2021) Extracellular Vesicles for the

Treatment of Radiation Injuries.

Front. Pharmacol. 12:662437.

doi: 10.3389/fphar.2021.662437
Normal tissue injury from accidental or therapeutic exposure to high-dose radiation can cause severe acute and delayed toxicities, which result in mortality and chronic morbidity. Exposure to single high-dose radiation leads to a multi-organ failure, known as acute radiation syndrome, which is caused by radiation-induced oxidative stress and DNA damage to tissue stem cells. The radiation exposure results in acute cell loss, cell cycle arrest, senescence, and early damage to bone marrow and intestine with high mortality from sepsis. There is an urgent need for developing medical countermeasures against radiation injury for normal tissue toxicity. In this review, we discuss the potential of applying secretory extracellular vesicles derived from mesenchymal stromal/stem cells, endothelial cells, and macrophages for promoting repair and regeneration of organs after radiation injury.

Keywords: acute radiation syndrome, radio mitigation, medical countermeasures against radiation, mesenchymal stromal/stem cells, endothelial cells, macrophages, extracellular vesicles, radiation injuries

\section{INTRODUCTION}

The first report of detrimental effects of ionizing radiation on healthy normal tissues came to light after the atomic bomb explosions in 1945. This unprecedented event introduced to the world the lethal radiation poisoning or sickness, also known as acute radiation syndrome (ARS), where a relatively large number of people can be affected by sudden exposure to high amounts of irradiation over a short period of time due to nuclear power plant accidents or atomic war. The extent of damage to an organism depends on the duration and the dosage of radiation with very high mortality after a threshold dose. ARS is a multi-organ failure syndrome caused by a combination of radiation dose-dependent direct cytocidal effects of irradiation on tissue stem and progenitor cells and the supporting sinusoidal endothelial and mesenchymal cells of the stem cell niche, with subsequent neutropenia, anemia, and thrombocytopenia due to bone marrow failure. With higher doses, manifestations of gastro-intestinal (GI)-ARS with loss of the intestinal mucosal barrier, bacteremia, septic shock, and systemic inflammatory response syndrome ensues. In addition to such accidental exposures, normal tissues succumb to radiation during radiotherapy in cancer patients, which is often unavoidable (Singh et al., 2018). For instance, in head and neck cancer patients, salivary glands are often present in the field of radiation (Coppes and Stokman, 2011), resulting in loss of stem cells, irreversible loss of saliva production over the years, leading to Xerostomia. Therefore, therapeutic strategies to ameliorate radiation-induced normal tissue toxicity are of great importance for tissues such as bone marrow, intestine, liver, and lung. 
At the cellular level, radiation exposure inflicts direct damage by ionizing biological macromolecules such as DNA, RNA, lipids, and proteins. Indirect damage to cells occurs via radiation-induced generation of reactive oxygen species (ROS), such as superoxide and hydroxide radicals from the radiolysis of intracellular water, which results in the oxidation of biological macromolecules. Radiation-induced singlestrand (SSBs) and double-strand DNA breaks (DSBs) are considered the major events leading to cell death, cell cycle arrest, and senescence (Panganiban et al., 2012).

Radiation medical countermeasures (MCMs) are agents administered either as preventive or as mitigators postexposure to radiation. The mitigators improve radiationinduced physiological damage such as cellular toxicity, apoptosis, and loss of stem cells. The radiation protectants prevent radiation-induced toxicity, for instance, by scavenging the free-radicals and reducing oxidative damage to cells. Several candidate MCMs were being identified and investigated (Singh and Seed, 2020). The cytokines Neupogen ${ }^{\circledR}$ (G-CSF), Neulasta ${ }^{\circledR}$ (pegylated G-CSF), Leukine ${ }^{\circledR} \quad$ (GM-CSF), and Nplate ${ }^{\circledR}$ (thrombopoietin receptor agonist) are radiation MCMs that received approval from the Food and Drug Administration (FDA) in the US for treating patients exposed to acute high doses of radiation that suppresses the functions of bone marrow and immune system.

\section{Organ Damage Induced by Radiation}

Mitotically active cells such as tissue-resident stem cells are more sensitive to radiation. Radiation-induced loss of stem cells is reported in multiple organs such as the bone marrow (Green and Rubin, 2014), intestine (Kulkarni et al., 2016), liver (Guha et al., 1999), lung (Giuranno et al., 2019), salivary gland (Coppes and Stokman, 2011; Rocchi and Emmerson, 2020), and brain (Leavitt et al., 2019). In the bone marrow, hematopoietic stem cells (HSCs) produce all the blood cell lineages (Bouchareychas et al., 2020). The HSC self-renewal capacity and differentiation potential are partly regulated by a complex multicellular network in the bone marrow microenvironment referred to as a niche. This bone marrow niche is composed of many different cell types such as mesenchymal stromal/stem cells (MSCs), adipocytes, osteocytes, and glial cells. Exposure to high-dose radiation during radiotherapy for leukemia and other bone malignancies results in the apoptosis of HSCs, decreasing their number and potential to self-renew and differentiate (Mendelson and Frenette, 2014). However, both in vitro and in vivo studies have shown that MSCs from bone marrow are relatively resistant to ionizing radiation and maintain their differentiation potential even exposure to high dose radiation (Singh et al., 2012; Nicolay et al., 2015; Ruhle et al., 2018). In addition to bone marrow cell loss, radiation also causes an increased endothelial cell (EC) permeability, imbalance in osteogenesis, damage to the bone microenvironment, and therefore infection susceptibility. The intestine is also a mitotically active tissue with actively proliferating crypt base cells identified as intestinal stem cells (ISCs), which are surrounded by MSCs, ECs, macrophages (M $\phi s)$, and lymphocytes. In addition to accidental exposure, radiotherapy for abdominal and kidney cancer patients causes damage to the intestine, resulting in loss of intestinal crypts, loss of mucosal barrier, and leading to microbial infection and inflammation (Kulkarni et al., 2016). Lung tissue is often exposed to radiation in patients undergoing radiotherapy for lung and esophageal cancers (Giuranno et al., 2019). This results in cell loss, edema of the alveolar walls, increased vascular permeability, and inflammation. Radiation-induced damage to the healthy liver occurs during radiotherapy for hepatocellular carcinoma resulting in occlusion of central vein lumina, EC toxicity, and hepatocellular atrophy (Guha et al., 1999; Benderitter et al., 2014). In addition to these acute effects, delayed toxicities were reported in most tissues leading to multi-organ failure. A schema on summary of the timeline and pathophysiologic changes following radiation exposure in different organs is represented in Figure 1.

\section{Cell Therapy and Limitations}

Stem cell therapy have been used to develop as radiation MCM (Rios et al., 2017). Stem cell transplantation led to the recovery of radiation-induced normal tissue toxicity in the bone (Becker et al., 1963), skin (Riccobono et al., 2012; Horton et al., 2013), salivary gland (Kojima et al., 2011; Lim et al., 2013; Nanduri et al., 2014; Maimets et al., 2016), brain (Acharya et al., 2015; Liao et al., 2017; Leavitt et al., 2019; Soria et al., 2019; Chu et al., 2020), and intestine (Saha et al., 2011; Gong et al., 2016; Zheng et al., 2016). Different types of stem cells were investigated in these studies for their potential to engraft, differentiate, repair, and regenerate radiation-damaged tissues. Allogenic bone marrow transplants are promising cell therapeutic strategies to recover radiationinduced bone marrow damage. However, challenges remain with the expansion and maintenance of HSCs in vitro (Walasek et al., 2012) and the ability of transplanted HSCs to engraft, self-renew and differentiate (Mendelson and Frenette, 2014). The number of resident stem cells in adult tissues is minimal and needs to be expanded in vitro to generate sufficient cells for the clinical translation. Moreover, stem cells' purification and selection strategies, such as flow-cytometry-based sorting, are not always suitable for clinical translation. Embryonic stem cells and genetically reprogrammed induced pluripotent stem cells (iPSC) or iPSC-derived differentiated cells such as hepatocytes, ECs are being investigated for regenerative application (Lee et al., 2019). Also, using the viral transduction methods to genetically engineer and modify the characteristics of the cells such as iPSCs poses a safety concern for clinical use. The transplantation of stem cells or MSCs may not have an immediate effect on attenuating organ injury. These transplanted cells need to be first engrafted in the body, and under some conditions, they need to further differentiate to other cell types to execute the needed biological activities. The long process of developing therapeutic effect by cell transplantation is not suitable for accidental radiation exposure where immediate repair and regenerative measures are required.

Studies have suggested that the secretome of various stem cells contains the critical growth factors and signaling molecules for the stem cell-driven regeneration via paracrine signaling route, mainly by extracellular vesicles (EVs) (Berger et al., 2017; Taheri 


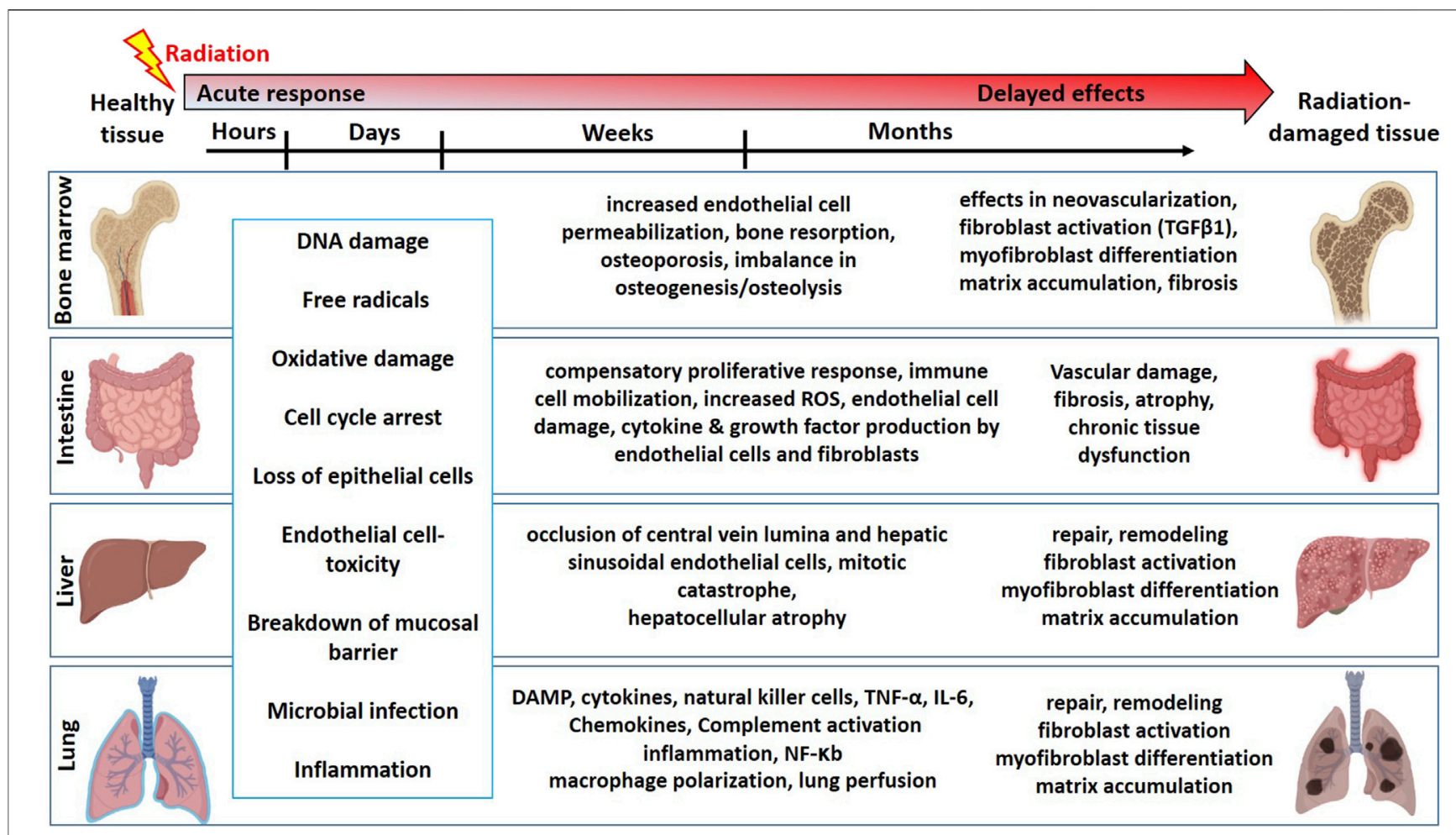

FIGURE 1 | The timeline and pathophysiologic changes in the bone marrow, intestine, liver, and lung for the development of normal tissue toxicity after high dose radiation exposure (Graphics adapted from BioRender.com).

et al., 2019). Therefore, EVs released from various cell types can be an alternative to cell therapeutics.

\section{Extracellular Vesicles Derived From Cells as Therapeutics}

EVs are the body's own nanoparticles that constitute a significant cell-to-cell communication system in multicellular organisms. According to the recent nomenclature stated by the International Society of Extracellular Vesicles (ISEV), EVs are broadly classified into plasma membrane-derived large microvesicles of $500-1,300 \mathrm{~nm}$ or endoplasmic reticulum-endosome derived small EVs of 30-200 nm (Thery et al., 2018). EV membranes contain various integrins, lipids, and proteins, each with a specific role; for instance, tetraspanins contribute to target cell selection (Rana et al., 2012). Molecules, such as CD9, CD63, CD81, tumor susceptibility gene 101 (TSG101), are used as signature biomarkers in the characterization of EVs; however, their expression levels vary, depending on the source of cell types. The content of EV and methodologies for characterizing EVs are summarized in Figure 2. Their unique nano-size, short life span makes EVs ideal messengers to travel between complex cellular fluid and selective membraned cellular structures. Depending on the cellular state of origin, EVs package either protein, small regulatory RNA, or lipids in addition to fragments of DNA (Witwer et al., 2019). However, the fate decisions that regulate this packaging are still under investigation.
Radiation stem cells and adversely affects the microenvironment. In the intestine, the stem cell niche supports ISC growth and crypt regeneration and is composed of MSCs, ECs, Mфs, and lymphocytes which are affected due to radiation. Transplantation of mouse bone marrow adherent stromal cell (BMASC) culture system enriched for MSCs $\left(\mathrm{CD} 0^{+} / \mathrm{CD} 105^{+} / \mathrm{CD} 29^{+}\right)$, myeloid cells $\left(\mathrm{CD} 45+/ \mathrm{CD}_{11 \mathrm{~b}}{ }^{+}\right)$, and ECs $\left(\mathrm{CD} 34^{+} / \mathrm{CD} 31^{+}\right)$improved the survival mice exposed to whole-body irradiation (WBI) (Saha et al., 2011). However, transplantation with the BMASC culture system depleted of myeloid cells or MSCs lost the beneficial effect. This study suggests that a combination of ECs, M $\phi$ s, and MSCs is necessary for the complete regeneration of the damaged intestine. In this review we have focused on the bone marrow derived MSC-, EC- and M $\phi$-derived EVs for radiation injuries.

\section{MESENCHYMAL STROMAL/STEM CELL-EVs}

Multipotent MSCs from multiple sources such as bone marrow, umbilical cord, and adipose tissue are the most widely tested stem cells. The regenerative potential of these cells is attributed to their multi-lineage differentiation potential, secretory, immunemodulatory, and homing capabilities (Viswanathan et al., 2019; Nolta et al., 2020). From 2008 to date, several clinical trials are in progress worldwide with MSCs for neurologic, 


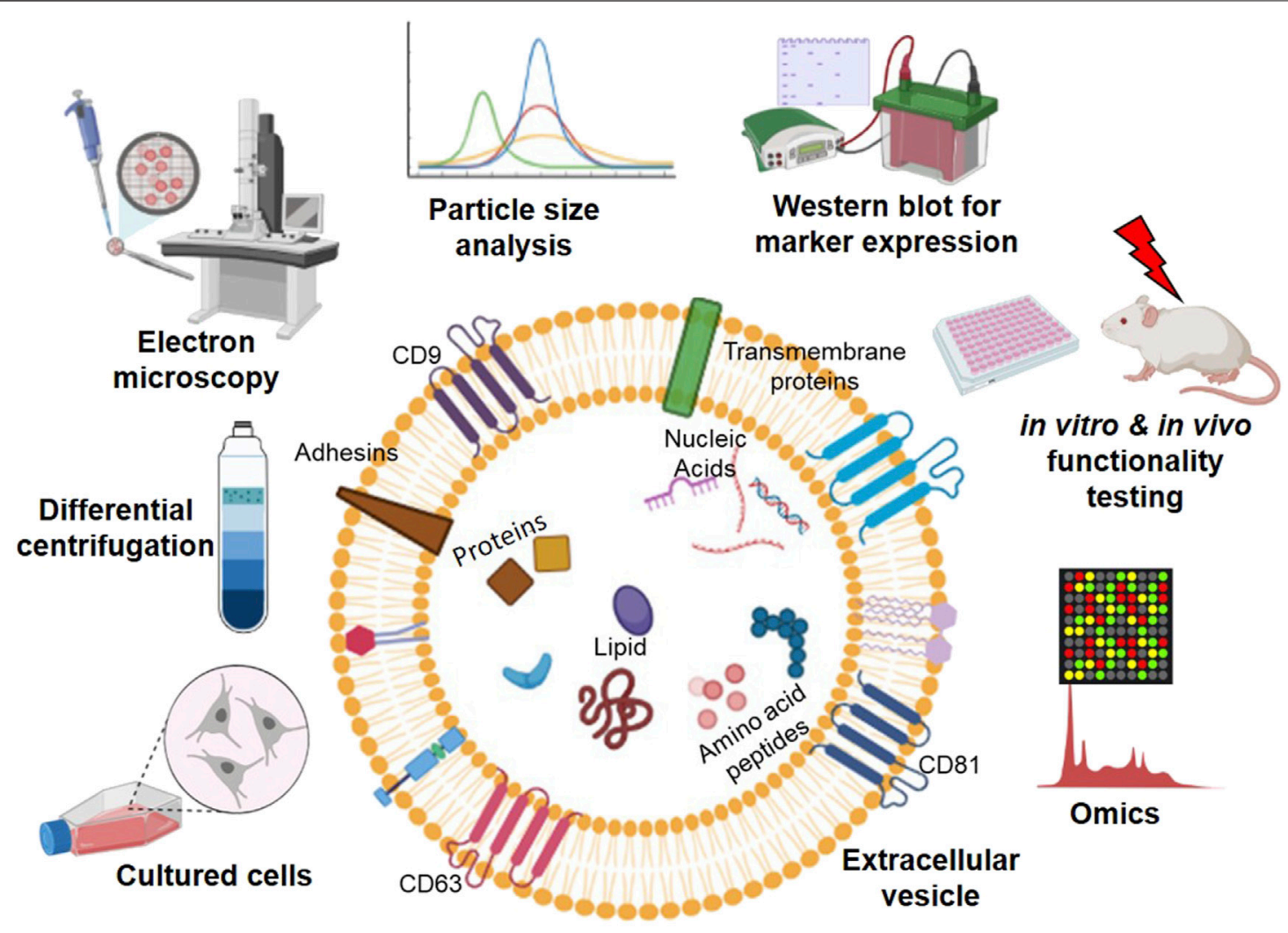

FIGURE 2 | An overview of workflow in studying extracellular vesicles (EVs). EVs contain a lipid bilayer membrane that encapsulates various molecules, including proteins, nucleic acids, amino acids/peptides, and lipids, for cell-to-cell communication. EVs are secreted from the cultured cells from various sources and isolated from the cell culture medium using ultracentrifugation. The isolated EVs can be characterized by (left to right on the top of EV) electron microscopy, particle size analysis, Western blotting, in vitro and in vivo functional testing, and high throughput-omics analysis (Graphics adapted from BioRender.com).

cardiovascular, pulmonary, liver, bone, skin, intestinal, and muscle abnormalities, including the most recent COVID-19 (Moll et al., 2019). The most common route of administration of MSCs is intravenous; however, intraperitoneal, subcutaneous routes are also being tested clinically (Kabat et al., 2020). In preclinical models, MSCs were shown to be distributed to lung, heart, and kidney after systemic transplantation. Recent reports have attributed this regenerative potential of MSCs to their paracrine signaling mechanism via EVs (Caplan and Dennis, 2006). In general, MSC-EVs package heterogeneous cargo such as nucleic acids, protein, and lipids. Studies have shown that $>150$ different miRNA are present in MSC-EVs to regulate a wide range of signaling pathways (Ferguson et al., 2018). The potential of MSCEVs to repair tissue injury was reported in the heart (Phinney and Pittenger, 2017), kidney (Zhang et al., 2016), lung (Wang et al., 2020), liver (Tan et al., 2014), intestine (Accarie et al., 2020), and cartilage (Wong et al., 2020). MSC-EVs were shown to be antiinflammatory, anti-oxidative, pro-angiogenic (Komaki et al., 2017), anti-fibrotic (Grange et al., 2019), promote epithelial cell growth (Gatti et al., 2011; Alcayaga-Miranda et al., 2016; Tsiapalis and O'Driscoll, 2020), improve myocardial infarction (Xu R. et al., 2019), promote M $\phi$ M2 polarization and wound healing.

\section{Biological Activities of Bone Marrow MSC-EVs}

Bone marrow-derived mesenchymal stromal/stem cells (BMMSCs) were first reported by Friedenstein et al. (1968). According to the International Society for Cell and Gene Therapy (ISCT), MSCs are defined as adherent cells possessing tri-lineage differentiation potential into osteocytes, chondrocytes, adipocytes, and express markers CD73, CD90, and CD105 (Dominici et al., 2006). The published materials from the last decade referred to in this review have analyzed one or a few of these properties to define the BMMSC population used to obtain EVs. Minimal information for studies of extracellular vesicles (MISEV) 2018 has given guidelines for the preparation of EVs from various BMMSCs (Thery et al., 2018; Witwer et al., 2019). Based on these guidelines, human MSCs need to be characterized as positive for CD105, CD73, CD90 expression and negative for CD45, CD34, CD14, CD11b, CD79 $\alpha$ or CD19. In addition, the differentiation potential of human BMMSCs into osteocytes, adipocytes, and chondrocytes needs to be confirmed.

EVs isolated from mice, rats, and human BMMSCs have been studied for their regenerative potential in different organ injury models (Table 1). Mouse BMMSC-EVs were reported to promote 
TABLE 1 | The biological effect of BMMSC-EVs on organ and cell repair in various non-radiation injury models.

\begin{tabular}{|c|c|c|c|c|c|}
\hline EV source & EV Characterization & Model & Effect & Signaling & References \\
\hline \multirow[t]{2}{*}{$\begin{array}{l}\text { Mouse BM } \\
\text { MSCs }\end{array}$} & $<200 \mathrm{~nm}$ & Traumatic brain injury & $\begin{array}{l}\text { Cognitive recovery, neuroblast } \\
\text { proliferation, reduced neural } \\
\text { inflammation }\end{array}$ & - & Zhang et al. (2015) \\
\hline & NTA & Necrotic entero colitis & Reduced intestinal toxicity & - & Rager et al. (2016) \\
\hline \multirow[t]{4}{*}{$\begin{array}{l}\text { Rat } \\
\text { BMMSCs }\end{array}$} & $\begin{array}{l}<300 \text { nm, EM, flow cytometry for } \\
\text { CD81, CD63 }\end{array}$ & $\begin{array}{l}\text { In vitro model of } \\
\text { Alzheimer's disease }\end{array}$ & Neuroprotective & $\begin{array}{l}\text { Catalase, reduced } \\
\text { oxidative stress }\end{array}$ & $\begin{array}{l}\text { de Godoy et al. } \\
\text { (2018) }\end{array}$ \\
\hline & $\begin{array}{l}<200 \text { nm EM, WB for HSP70, } \\
\text { TSG101, CD63, CD81 }\end{array}$ & Myocardial injury & $\begin{array}{l}\text { Reduce inflammation, promote M2 } \\
\text { macrophage polarization }\end{array}$ & $N F-\kappa B$ & Xu et al. (2019a) \\
\hline & $\begin{array}{l}<200 \text { nm, EM, WB for CD63, } \\
\text { CD81, Alix }\end{array}$ & Myocardial infarction & Inhibition of myocardial infarction & $\begin{array}{l}\text { ATG13, mTOR, } \\
\text { autophagy }\end{array}$ & Zou et al. (2019) \\
\hline & $\begin{array}{l}<200 \text { nm, EM, WB for CD63, } \\
\text { CD81, CD9 }\end{array}$ & Bone fracture & $\begin{array}{l}\text { Endothelial cell proliferation, osteoblast } \\
\text { proliferation }\end{array}$ & $\begin{array}{l}\text { HIF-1 } \alpha-\text { VEGF, BMP- } \\
\text { 2/Smad1/RUNX2 }\end{array}$ & $\begin{array}{l}\text { Zhang et al. } \\
\text { (2020a) }\end{array}$ \\
\hline \multirow[t]{5}{*}{$\begin{array}{l}\text { Human } \\
\text { BMMSCs }\end{array}$} & EM, immunolabeling CD9, CD63 & Acute kidney injury & Proliferate proximal tubular epithelial cells & IGF-1 & $\begin{array}{l}\text { Tomasoni et al. } \\
\text { (2013) }\end{array}$ \\
\hline & $\begin{array}{l}<200 \text { nm, EM, WB for CD9, } \\
\text { Flotillin1 }\end{array}$ & Angiogenesis assays & Endothelial cell proliferation & EMMPRIN & Vrijsen et al. (2016) \\
\hline & EM, CD63 ELISA & Optical nerve crush & Retinal ganglion cell protection & - & $\begin{array}{l}\text { Mead and } \\
\text { Tomarev (2017) }\end{array}$ \\
\hline & $\begin{array}{l}<200 \text { nm, EM, WB for CD9, CD63, } \\
\text { CD81, TSG101, Alix }\end{array}$ & $\begin{array}{l}\text { Carbon tetrachloride- } \\
\text { induced liver fibrosis }\end{array}$ & $\begin{array}{l}\text { Improved liver function reduced } \\
\text { inflammation and fibrosis }\end{array}$ & Wnt/ $\beta$-catenin & Rong et al. (2019) \\
\hline & $\begin{array}{l}<200 \mathrm{~nm}, \mathrm{EM}, \text { WB for CD9, CD63, } \\
\text { CD81 }\end{array}$ & Rat calvaria bone defect & Bone regeneration, angiogenesis & VEGF, ANG1, ANG2 & $\begin{array}{l}\text { Takeuchi et al. } \\
\text { (2019) }\end{array}$ \\
\hline
\end{tabular}

angiogenesis via extracellular matrix metalloproteinase inducer (Vrijsen et al., 2016), stabilize endothelial-barrier function via hepatocyte growth factor (Wang et al., 2017). Rat BMMSC-EVs were reported to reduce oxidative stress via catalase (de Godoy et al., 2018), improve cognitive recovery, and reduce neural inflammation in the traumatic brain injury model (Zhang et al., 2015).

\section{BMMSC-EVs for Radiation-Induced Bone Marrow Injury}

Mitotically active bone marrow is highly susceptible to radiation. Exposure to radiation results in increased vascular permeability, loss of hematopoietic stem-progenitor cells, osteopenia, arrest of bone growth, and bone marrow stromal cell apoptosis, eventually leading to fibrosis (Pacheco and Stock, 2013).

Murine BMMSC $\left(\mathrm{CD} 44^{+} / \mathrm{CD} 24^{+} / \mathrm{CD} 105^{+} / \mathrm{Sca}-1^{+}\right.$and $\mathrm{CD} 31^{-} /$ $\left.\mathrm{CD} 11 \mathrm{~b}^{-} / \mathrm{CD} 45^{-} / \mathrm{CD} 34^{-} / \mathrm{CD} 86^{-}\right)$derived EVs could rescue bone marrow hematopoietic cells from radiation damage in vitro and in vivo (Wen et al., 2016). In this study, when treated with murine BMMSC-EVs, the irradiated mouse hematopoietic cell line (Factor Dependent Continuous-Paterson 1) showed increased proliferation and reduced apoptosis. The authors further studied the potential of mouse and human BMMSC-EVs to rescue murine hematopoietic radiation damage in vivo. Seven days post 1 Gy WBI of B6. SJL mice, bone marrow-lineage negative cells were isolated and cultured with $2 \times 10^{9}$ murine MSC-EV particles $/ \mathrm{ml}$ or vehicle for $48 \mathrm{~h}$. These cells were intravenously injected into 2 Gy WBI C57BL/6 mice. Mice that received BMMSC-EV treated irradiated bone marrow hematopoietic cells showed a significant increase in engraftment at 36 weeks compared to those transplanted with vehicle-treated cells. Whole bone marrow cells that were harvested at 36-weeks post- transplant were able to recover the bone marrow after secondary transplantation into lethally irradiated mice. Similarly, intravenous injection of $4 \times 10^{9}$ human MSC-EV particles/ml into 5 Gy WBI mice showed improved granulocytes and white blood cells at three and five weeks post-radiation.

Another report from the same group investigated the biodistribution of DiD-labelled MSC-EVs in irradiated bone marrow using different doses, injection schedules, and timing postradiation (Wen et al., 2019). They showed that 5 Gy WBI mice treated with BMMSC-EVs had a significant increase in the uptake of EVs by $\mathrm{CD} 11 \mathrm{~b}^{+}$and $\mathrm{F} 4 / 80^{+}$cells in the spleen compared to that of femur bone marrow at 6 and $24 \mathrm{~h}$ postradiation. Besides, an increase in uptake of EVs was observed in a radiation dose-dependent manner when injected $6 \mathrm{~h}$ postradiation into mice at 1,3 , or 6 Gy radiation. This study also reported a dose-dependent increase in $\mathrm{EV}$ uptake in bone marrow, spleen, and liver when injected with $2 \times 10^{8}, 2 \times 10^{9}$, and $2 \times 10^{10}$ particles of BMMSC-EVs, $24 \mathrm{~h}$ post-5 Gy WBI. Similarly, after three intravenous injections of $2 \times 10^{9} \mathrm{EV}$ particles to 5 Gy WBI mice, a significant increase in EV load was observed in the liver and spleen compared to a single injection.

Zuo et al. (2019) reported that Sprague-Dawley rat BMMSCEVs alleviate radiation-induced bone loss in rats that received 16 Gy Cesium radiation to the knee joint of the left hind limb (Zuo et al., 2019). In their study, BMMSC-EVs were isolated via ultracentrifugation and were $<100 \mathrm{~nm}$ in size, expressed CD63, CD81, TSG101, and negative for Calnexin. The amount of EVs at $1.6 \mathrm{mg} / \mathrm{kg}$ or $1 \times 10^{6}$ BMMSCs were injected into the tail vein of $16 \mathrm{~Gy}$ irradiated rats. Bone volume fraction (BV/TV) is the parameter to determine the volume of mineralized bone per unit volume of the sample. The BV/TV of the non-irradiated 
mice was $67.6 \%$, while it was decreased to $30.9 \%$ in the irradiated mice 28 days post-radiation. However, the $\mathrm{BV} / \mathrm{TV}$ of the irradiated mice transplanted with BMMSCs and BMMSC-EVs was increased by 53 and 13\%, respectively, compared to the irradiated mice without transplantation. Furthermore, incubation of BMMSC-EVs with 6 Gy irradiated BMMSCs in vitro showed a decrease in DSB as determined by $\gamma$-H2AX staining at 2,4 , and $12 \mathrm{~h}$ post-radiation; an increase in antioxidant effect via increasing the expression of superoxide dismutase (SOD) 1 and 2 at $12 \mathrm{~h}$ and $24 \mathrm{~h}$ post-radiation and activation of Wnt/ $\beta$-catenin signaling in BMMSCs, which could be the mechanisms of improving bone loss observed in irradiated rats with BMMSCEV treatment. This study also showed that BMMSC-EVs treatment restored the radiation-induced loss of BMMSCs differentiation potential as indicated by an increase in calcium deposition, Runx2 expression (osteogenic), and oil red $\mathrm{O}$ staining (adipogenic) compared to irradiated cells without treatment (Zhou et al., 2018).

\section{BMMSC-EVs for Radiation-Induced Intestinal Injury}

Stem cell-driven regeneration in the intestine is mediated by cycling leucine-rich repeat-containing G-protein coupled receptor 5 $\left(\operatorname{Lr} 5^{+}\right)$stem cells at the crypt base via a Wnt signaling pathway (Barker et al., 2007). These crypts are in close contact with stromal cells such as mesenchymal cells, ECs, M $\phi$ s, and lymphocytes that provide the signaling factors for intestinal regeneration. Radiation damage to the intestine leads to the loss of these rapidly cycling Lgr $5^{+}$stem cells to the impairment of epithelial regeneration, showing an irreversible loss of crypt-villi, EC apoptosis, and loss of mucosal barrier. Collectively these contribute to septic shock and systemic inflammatory response as a radiation-induced gastrointestinal syndrome.

Accarie et al. (2020) has shown that EVs that are $<250 \mathrm{~nm}$ and $\mathrm{CD} 1^{+}$derived from human BMMSCs mitigate intestinal toxicity in a mouse model of ARS (Accarie et al., 2020). This study compared the effect of intravenous injection of $600 \mu \mathrm{g}$ of BMMSC-EVs after 10 Gy WBI. A 3.5-days delay in death was observed in nude mice that received three injections of BMMSCEVs at 6, 24, and $48 \mathrm{~h}$ post-10 Gy WBI in comparison to untreated, irradiated control mice. Also, the expression of tight junction protein claudin-3 was more preserved at the membrane of small intestine epithelium in BMMSC-EV treated mice than in irradiated, non-treated controls. At 3 days post-WBI, a dosedependent decrease in apoptotic cells, an increase in $\mathrm{Ki} 67^{+}$cells in the crypts, and less alteration of crypt-villus architecture was observed in BMMSC-EV-treated mice in comparison to the irradiated mice without treatment.

The direct effect of human BMMSC-EVs on the ISCs after radiation has not been studied yet. Reserve ISCs like radioresistant cells expressing Keratin19 (Krt19) (Asfaha et al., 2015) and Polycomb complex protein (Bmil) (Yan et al., 2012) were shown to be generating $\operatorname{Lgr}^{+}$cells for recovering the functional cell loss after radiation. However, other growth factors and EVs from multiple cell sources that can stimulate these stem cells need to be further investigated.

\section{BMMSC-EVs for Radiation-Induced Liver Injury}

During radiotherapy for hepatocellular carcinoma, normal liver tissue is often exposed to radiation. This results in liver sinusoidal endothelial cell toxicity, atrophy of hepatocytes, and occlusion of veins, gradually leading to loss of liver function and progressing toward radiation-induced liver disease (RILD) or radiation hepatitis (Benderitter et al., 2014). An increase in inflammatory cytokines such as tumor necrosis factor-alpha (TNF- $\alpha$ ), interleukin (IL)- $1 \beta$, and IL- 6 was observed in the early phase of RILD. Currently, there is no effective treatment for RILD.

Congenic hepatocyte transplantation via intra-splenic injection is shown to repair acute and late effects of RILD (Guha et al., 1999). Intra-splenic transplantation of liver sinusoidal endothelial cells combined with hepatocyte growth factor into partial hepatic irradiation rodent model was shown to ameliorate radiation-induced sinusoidal obstructive syndrome and repopulate the irradiated sinusoidal endothelium by eight weeks after transplantation (Kabarriti et al., 2010). Challenges with orthotropic liver transplantation and the minimal availability of donor hepatocytes for safe transplant limit the use of hepatocyte transplantation to treat liver diseases.

EVs derived from MSCs from the human umbilical cord ( $\mathrm{Li}$ et al., 2013), bone marrow (Rong et al., 2019), and embryonic stem cells (Tan et al., 2014) have been reported to alleviate liver injury in drug-induced hepatic injury models (Lou et al., 2017; Phinney and Pittenger, 2017). Herrera et al. (2010) have shown that microvesicles derived from human liver stem cells $\left(\mathrm{CD} 29^{+} /\right.$ $\mathrm{CD} 44^{+} / \mathrm{CD} 3^{+} / \mathrm{CD} 0^{+}$) accelerated liver regeneration in $70 \%$ hepatectomized rats (Herrera et al., 2010). Rong et al. (2019) showed that human BMMSC-EVs $(<200 \mathrm{~nm})$ effectively alleviated liver fibrosis by inhibiting $\mathrm{Wnt} / \beta$-catenin signaling in the carbon tetrachloride -induced liver damage model (Rong et al., 2019). Even though MSC-EVs were shown to alleviate various drug-induced or physical hepatic injury models, their potential to recover radiation-induced liver injury is not well studied.

\section{BMMSC-EVs for Radiation-Induced Lung Injury}

Radiation-induced pneumonitis and radiation-induced pulmonary fibrosis are the major early and delayed lung toxicities in cancer patients undergoing thoracic radiotherapy. Radiation-induced DNA damage and free radicals result in epithelial cell death leading to lung mucositis. This is followed by an increase in inflammatory cytokines (TNF- $\alpha$ and IL-6), natural killer (NK) cells, $\mathrm{M} \phi$ polarization, edema, and lung perfusion, eventually activating fibroblasts and myofibroblast differentiation to fibrosis in the irradiated lung (Kabarriti et al., 2020). MSCs derived from the umbilical cord (Wei et al., 2020), bone marrow (Lee et al., 2012), and adipose tissue (Dong et al., 2015) were reported to be attenuating various models of lung injury.

Human umbilical cord-MSCs could repair radiation-induced lung injury (RILI) by inhibiting myofibroblastic differentiation of 
human lung fibroblasts (Xu S. et al., 2019; Zhang et al., 2019). Human adipose-MSCs were shown to downregulate TNF- $\alpha$ signaling in the 15 Gy-irradiated lungs and prevent the epithelial-mesenchymal transition of irradiated type II alveolar epithelial cells (Dong et al., 2015). Klein 2017 showed that conditioned media from aorta-MSCs restored SOD1 expression and protected EC loss in the lung of RILI mice (Klein et al., 2017). These studies have demonstrated the effectiveness of using different sources of MSCs, which warrants further investigation on MSC-EVs for treating RILI.

\section{ENDOTHELIAL CELL-EVs}

The heart pumps the blood carrying nutrients and oxygen to all the cells in our body via arteries to capillaries and collects the blood via veins for waste removal and purification. The collective action of the blood vascular system and lymphatics maintains the fluid level in the body. All these vessels are lined by ECs that play an important role in vascular homeostasis. In addition, ECs mediate immune responses, involve in inflammation, coagulation, and angiogenesis (Orfanos et al., 2004). ECs differ based on their location; for instance, micro versus macrovascular ECs have a distinct response to physiologic and inflammatory stimuli (Stevens et al., 2008).

Radiation induces EC dysfunction, such as increased permeability, apoptosis, and detachment from the basement membrane of the vessels (Flamant and Tamarat, 2016). This often leads to inflammation, fibrosis, and damage to tissue microvasculature depending upon the radiation dose. Radiation-induced EC toxicity is reported in various tissues such as the intestine (Paris et al., 2001; Wang et al., 2007), lungs (Ghobadi et al., 2012; Ziegler et al., 2017), central nervous system (Peña et al., 2000), and parotid glands (Xu et al., 2010). Ionizing radiation-induced long-term senescence was reported in ECs (Lafargue et al., 2017). Prevention or inhibition of EC toxicity was reported to protect the intestine (Rotolo et al., 2012), central nervous system (Peña et al., 2000), and lungs (Klein et al., 2017) against radiation-induced damage. EC transplantation has been shown to be beneficial in mouse models of hemophilia (Follenzi et al., 2008), hepatectomy (Melgar-Lesmes et al., 2017), and lethal irradiation in mice (Chute et al., 2007).

\section{Biological Activities of EC-EVs}

Like many mammalian cells, ECs respond to stimuli and produce heterogeneous cargo containing EVs. A distinct proteomic cargo was reported in human umbilical vein endothelial cells (HUVECs) when stimulated with TNF- $\alpha$ (Letsiou and Bauer, 2018). Similar changes were reported in the proteome cargo of EVs from human pulmonary artery endothelial cells treated with mechanical cyclic stretch or lipopolysaccharides (Letsiou et al., 2015). Van Balkom 2015 analyzed the miRNA profile of human microvascular endothelial cells (HMEC-1) and thus-derived EVs. The study showed that EC-EVs contain miRNA's related to the regulation of angiogenesis, proliferation, and differentiation (van Balkom et al., 2015). Endothelial progenitor cell-EVs were shown to improve atherosclerotic endothelial dysfunction in a mouse model of atherosclerotic diabetes (Bai et al., 2020). EC-EVs were shown to enhance EC proliferation (Wang et al., 2019) and act against apoptosis and inflammation (Andrews and Rizzo, 2016). EC-EVs from various sources were shown to be neuroprotective (Xiao et al., 2017), improve sepsis (Zhou et al., 2018), and improve high D-glucose-induced endothelial dysfunction (Saez et al., 2018).

HUVEC-EVs were shown to protect human neuroblastoma $\mathrm{SH}-\mathrm{SY} 5 \mathrm{Y}$ cells from ischemia-reperfusion injury in vitro (Xiao et al., 2017). Endothelial colony-forming cells (ECFC)-EVs inhibited apoptosis and reduced ischemic kidney injury in mice (Vinas et al., 2018). Brain EC-EVs promoted motor function and Synapsin I expression in the cerebral artery occlusion model of rats (Gao et al., 2020). EVs from HUVECs cultured in high glucose media restored wound healing of basal glucose cultured HUVECs compared to EVs from HUVECs cultured in basal media (Saez et al., 2018). EVs isolated from HUVECs cultured under high glucose increase intercellular adhesion molecule 1 (ICAM1) expression in Mono-Mac-6 cells, a monocytic cell line (Saez et al., 2019). HUVEC-EVs showed a decrease in cardiomyocyte death, protected against hypoxia via extracellular signal-regulated protein kinase (ERK1/ 2) and mitogen-activated protein kinase (MAPK) signaling (Davidson et al., 2018). The cardioprotective effect was not observed when treated with EV depleted conditioned media. Increased axonal growth and upregulation of miRNA related to the regulation of Sema6A, Phosphatase and Tensin Homolog (PTEN), and RhoA was observed with rat cerebral EC-EVs in vitro (Zhang Y. et al., 2020). Vascular smooth muscle cells showed an increased vascular cell adhesion molecule 1 (VCAM1) expression and leukocyte adhesion when cultured with rat cerebral EC- EVs (Boyer et al., 2020). The summary of utilizing various biological activities of EC-EVs in treating different non-radiation injury models discussed in this review are listed in Table 2.

\section{EC-EVs for Radiation-Induced Bone Marrow Injury}

The bone marrow microenvironment regulates HSC fate in homeostasis and after injury (Mendelson and Frenette, 2014). In addition to osteoblasts and stromal cells, ECs occupy a significant role in niche signals for HSCs, and EC toxicity is one of the major consequences of multi-organ failure in ARS. Piryani et al. (2019) studied whether EC-EVs could regulate HSC regeneration after ionizing radiation (Piryani et al., 2019). EVs were isolated from bone marrow ECs of C57BL/6 mice via differential centrifugation to obtain $<200 \mathrm{~nm}$ in size and expressed CD31, vascular endothelial (VE)-cadherin. At $24 \mathrm{~h}$ after either 5 Gy (hematopoietic assays) or 8 Gy (for survival) WBI, $1.9 \times 10^{9}$ particles of EV were intravenously injected daily for four days. Irradiated mice with EC-EV treatment showed improved bone marrow cellularity, hematopoietic stem and progenitor cell content, preserved EC architecture, and showed a $50 \%$ survival advantage. Among the 48 cytokines tested, ECEVs increased the expression level of tissue inhibitor of 
TABLE 2 | The biological effect of endothelial cell-EVs on organ and cell repair in various non-radiation injury models.

\begin{tabular}{|c|c|c|c|c|c|}
\hline EV source & EV Characterization & Model & Effect & Signaling & References \\
\hline HUVECS & $\begin{array}{l}<200 \text { nm, EM, WB for CD9, } \\
\text { HSP70, TSG101 }\end{array}$ & $\begin{array}{l}\text { Cerebral ischemia- } \\
\text { reperfusion injury }\end{array}$ & SH-SY5Y nerve cell protection & - & $\begin{array}{l}\text { Xiao et al. } \\
(2017)\end{array}$ \\
\hline ECFCs & $\begin{array}{l}<200 \text { nm, WB for CD81, } \\
\text { TSG101 }\end{array}$ & Kidney ischemic injury & $\begin{array}{l}\text { Inhibition of apoptosis, reduced } \\
\text { ischemic injury }\end{array}$ & $\begin{array}{l}\text { miR-486-5p, } \\
\text { PTEN }\end{array}$ & $\begin{array}{l}\text { Vinas et al. } \\
(2018)\end{array}$ \\
\hline Senescent HUVECs & $\begin{array}{l}\text { EM, WB for CD63, CD9; } \\
\text { Calnexin, } \beta \text {-actin negative }\end{array}$ & HUVECs in vitro & $\begin{array}{l}\text { Decreases in VE-cadherin, } \beta \text {-catenin, } \\
\text { decreased cell growth and impaired } \\
\text { migration potential }\end{array}$ & $\beta$-catenin & $\begin{array}{l}\text { Wong et al. } \\
\text { (2019) }\end{array}$ \\
\hline HUVECS & $\begin{array}{l}<200 \mathrm{~nm} \text {, EM, flow cytometry } \\
\text { for CD63 }\end{array}$ & $\begin{array}{l}\text { Adult rat cardiomyocytes co- } \\
\text { culture in vitro }\end{array}$ & $\begin{array}{l}\text { Decreased cell death of } \\
\text { cardiomyocytes, protection against } \\
\text { hypoxia }\end{array}$ & $\begin{array}{l}\text { ERK } 1 / 2 \\
\text { MAPK }\end{array}$ & $\begin{array}{l}\text { Davidson et al. } \\
\text { (2018) }\end{array}$ \\
\hline $\begin{array}{l}\text { HUVECs conditioned } \\
\text { with basal and high } \\
\text { glucose }\end{array}$ & $\begin{array}{l}<300 \mathrm{~nm}, \mathrm{EM}, \mathrm{WB} \text { for CD63, } \\
\text { CD81 }\end{array}$ & $\begin{array}{l}\text { HUVECs growth, wound } \\
\text { healing in vitro }\end{array}$ & $\begin{array}{l}\text { Induced endothelial dysfunction in } \\
\text { HUVECs }\end{array}$ & ICAM-1 & $\begin{array}{l}\text { Saez et al. } \\
(2018)\end{array}$ \\
\hline HUVECs and monocytes & $<300$ nm, EM, WB for CD63 & $\begin{array}{l}\text { Monocytes (MM6) and } \\
\text { HUVECs under high glucose } \\
\text { in vitro }\end{array}$ & $\begin{array}{l}\text { Increase ICAM-1 expression in MM6 } \\
\text { cells }\end{array}$ & ICAM-1 & $\begin{array}{l}\text { Saez et al. } \\
\text { (2019) }\end{array}$ \\
\hline Brain ECs (bEnd.3) & EM & $\begin{array}{l}\text { Rat cerebral artery occlusion } \\
\text { model }\end{array}$ & $\begin{array}{l}\text { Promoted motor function, synapsing in } \\
\text { dendrites }\end{array}$ & miR-126-3p & $\begin{array}{l}\text { Gao et al. } \\
(2020)\end{array}$ \\
\hline $\begin{array}{l}\text { Rat cerebral ECs (CECs) } \\
\text { and ischemic-CECs }\end{array}$ & $\begin{array}{l}<200 \text { nm, EM, WB for CD63, } \\
\text { CD31, Alix; calnexin, zo-1 } \\
\text { negative }\end{array}$ & Axon culture in vitro & $\begin{array}{l}\text { Increased axonal growth, upregulation } \\
\text { of miRNA }\end{array}$ & $\begin{array}{l}\text { Sema6A, } \\
\text { PTEN, and } \\
\text { RhoA }\end{array}$ & $\begin{array}{l}\text { Zhang et al. } \\
\text { (2020b) }\end{array}$ \\
\hline $\begin{array}{l}\text { Rat aortic endothelial and } \\
\text { vascular smooth muscle } \\
\text { cells }\end{array}$ & $\begin{array}{l}<200 \text { nm, EM, WB forTSG101, } \\
\text { Flotillin; VDAC negative }\end{array}$ & $\begin{array}{l}\text { Vascular smooth muscle } \\
\text { cells in vitro }\end{array}$ & $\begin{array}{l}\text { Increased VCAM1 expression and } \\
\text { leukocyte adhesion to vascular smooth } \\
\text { muscle cells }\end{array}$ & HMGB1 & $\begin{array}{l}\text { Boyer et al. } \\
(2020)\end{array}$ \\
\hline
\end{tabular}

metalloproteinase 1 , which is essential in vascular remodeling post-ischemia (Mandel et al., 2017). The above study suggests that EC-EVs have the potential to protect post-radiation damaged ECs.

A thorough investigation needs to be performed to examine EC-EVs as radiation MCM to mitigate injury in other organs such as the intestine, liver, and lung. Specific types of ECs have distinct potential and actions (Rafii et al., 2016). The characteristics of EVs from various cell types such as the aorta, endothelial progenitor cells, and organs such as lung and liver need to be studied to facilitate tissue-specific regeneration after radiation injury.

\section{MACROPHAGE-EVs}

Macrophages are the phagocytic immune cells that originate from monocytes and circulate in the blood. They differentiate in various tissues as tissue-resident $M \phi$ s such as alveolar $M \phi s$ in the lung, Kupffer cells in the liver, microglia in the brain, and splenic $M \phi s$ in the spleen. They are distinguished by their morphology, the pathogens they interact with, the levels and type of cytokines they produce. They present antigens to T-cells and initiate inflammation, release cytokines that activate other immune cells. Inflammatory monocytes and tissue-resident $\mathrm{M} \phi \mathrm{s}$ play a crucial role in tissue repair, regeneration, and fibrosis. Insults to healthy tissues result in increased release of damageassociated molecular patterns (DAMPs). This initiates an inflammatory cascade involving recruitment, proliferation, and activation of various hematopoietic and non-hematopoietic mediators (neutrophils, Mфs, innate lymphoid cells (ILCs), NK cells, B cells, T cells, fibroblasts, epithelial cells, ECs, and stem cells) which collectively work for tissue repair (Wynn et al., 2013). $\mathrm{M} \phi \mathrm{s}$ are a great source of Wnt ligands that activate epithelial regeneration potential in injury models of the liver (Boulter et al., 2013) and kidney (Lin et al., 2010). However, Mфs undergo reprogramming in response to the damage signals and can be pro-inflammatory M1 or anti-inflammatory M2 phenotype. M1 and $\mathrm{M} 2 \mathrm{M} \phi$ s possess distinct chemokine profiles and differ in the metabolism of iron, folate, and glucose (Mantovani et al., 2013). $\mathrm{M} \phi$ s are studied widely for their role in tissue repair and their potential for tissue regeneration.

\section{Biological Activities of $\mathbf{M} \phi-E V s$}

$\mathrm{M} \phi$-EVs are gaining a lot of interest as therapeutics. Tissue repair potential of $\mathrm{M} \phi$-EVs was reported in models of atherosclerosis (Bouchareychas et al., 2020), cardiac injury (Dai et al., 2020), wound healing (Li et al., 2019), hair loss (Rajendran et al., 2020), dextran sulfate sodium induced-colitis (Schubart et al., 2019; Yang et al., 2019), vascular repair in intravascular stunt-implant (Wallis et al., 2020) and skin diseases (Kim et al., 2019). M $\phi-E V s$ from various sources were shown to be angiogenic (Yan et al., 2020), influence neural action potential (Vakili et al., 2020), antiinflammatory, and could convert M1 to M2 polarization (Kim et al., 2019). M2 M $\phi$-EVs were shown to be antiinflammatory in the atherosclerosis model by reducing nuclear factor kappa-light-chain-enhancer of activated B cells (NF- $\kappa$ B) and TNF- $\alpha$ signaling (Bouchareychas et al., 2020). M $\phi-$ EVs were shown to promote Wnt-signaling for hair growth (Rajendran et al., 2020) and intestinal regeneration (Saha et al., 2016). The summary of various biological activities of M $\phi$-EVs in treating different non-radiation organ injury models as discussed in this review is listed in Table 3. 
TABLE 3 | The biological effect of macrophage-EVs on organ repair in various non-radiation injury models.

\begin{tabular}{|c|c|c|c|c|c|}
\hline EV source & EV Characterization & Model & Effect & Signaling & References \\
\hline $\begin{array}{l}\text { Murine bone marrow-derived } \\
\text { macrophages (BMDM) and } \\
\text { BMDM-treated with IL-4 }\end{array}$ & $\begin{array}{l}<200 \mathrm{~nm}, \text { EM, WB for } \\
\text { CD9, Alix, Flotillin }\end{array}$ & Atherosclerosis & $\begin{array}{l}\text { Reduced excessive hematopoiesis in bone } \\
\text { marrow, number of macrophages; } \\
\text { reduction in necrotic lesions }\end{array}$ & $\begin{array}{l}\text { miRNA regulation } \\
\text { of } \mathrm{NF}-\mathrm{kB}, \mathrm{TNF}-\mathrm{a}\end{array}$ & $\begin{array}{l}\text { Bouchareychas } \\
\text { et al. (2020) }\end{array}$ \\
\hline Murine RAW 264.7 cells & $\begin{array}{l}<200 \mathrm{~nm}, \mathrm{EM}, \text { WB for } \\
\text { CD63, Alix }\end{array}$ & Diabetic rat & $\begin{array}{l}\text { Inhibited secretion of pro-inflammatory } \\
\text { cytokines, induced endothelial cell } \\
\text { proliferation, migration and re- } \\
\text { epithelialization of the wound }\end{array}$ & $\begin{array}{l}\text { TNF- } \alpha, \text { IL- } 6 \\
\text { inhibition, P-AKT } \\
\text { activation }\end{array}$ & Li et al. (2019) \\
\hline $\begin{array}{l}\text { Murine bone marrow-derived } \\
\text { M2b macrophages }\end{array}$ & $\begin{array}{l}<200 \mathrm{~nm}, \mathrm{EM}, \mathrm{WB} \text { for } \\
\text { CD9, CD63, CD81 }\end{array}$ & DSS-colitis & $\begin{array}{l}\text { Increase in Treg cells, IL-4 in the spleen, } \\
\text { suppression of IL-1 } \beta, I L-6, I L-17 A\end{array}$ & CCL1/CCR8 & Yang et al. (2019) \\
\hline $\begin{array}{l}\text { Murine bone marrow-derived } \\
\text { M2 macrophages }\end{array}$ & $\begin{array}{l}<200 \mathrm{~nm}, \mathrm{EM}, \mathrm{WB} \text { for } \\
\text { CD63, Alix }\end{array}$ & $\begin{array}{l}\text { Cutaneous wound } \\
\text { mice model }\end{array}$ & $\begin{array}{l}\text { Increased M2 at the wound site, increased } \\
\text { angiogenesis, re-epithelialization and } \\
\text { collagen deposition }\end{array}$ & $\begin{array}{l}\text { Activation of } \\
\text { arginase, } \\
\text { inhibition of iNOS }\end{array}$ & Kim et al. (2019) \\
\hline
\end{tabular}

\section{$M \phi-E V s$ for Radiation-Induced Intestine Injury}

Saha et al. (2011) have developed an enrichment culture system from mouse BMASCs containing MSCs $\left(\mathrm{CD} 90^{+} / \mathrm{CD} 105^{+} / \mathrm{CD} 29^{+}\right)$, myeloid cells $\left(\mathrm{CD} 45+/ \mathrm{CD} 11 \mathrm{~b}^{+}\right)$, and ECs $\left(\mathrm{CD} 34^{+} / \mathrm{CD} 31^{+}\right)$(Saha et al., 2011). After transplanting into mice subjected to $18 \mathrm{~Gy}$ abdominal radiation, BMASCs have promoted ISC regeneration and improved their survival, whereas either depletion of myeloid cells or MSCs failed to regenerate the irradiated intestine, suggesting that myeloid cells and MSC mediated regeneration. Mфs support crypt regeneration, coordinate signals from gut microbes, injured epithelium, and help ISC regeneration (Pull et al., 2005). M $\phi$ s activated by toll-like receptor 9 was shown to ameliorate intestinal injury post-radiation (Saha et al., 2011). Wnt signaling has an important role in ISC proliferation and regeneration in the intestine. Earlier reports from our group by Saha et al. (2016) have studied M $\phi-E V$ s for intestinal regeneration. To understand the specific role of Wnt signing from M $\phi$ s for intestinal repair, this study generated mice with macrophage-restricted ablation of Porcupine $\left(\right.$ Porcn $\left.^{\mathrm{f} / \mathrm{fl}}\right)$, a gene essential for Wnt synthesis. These Porcn-depleted (null) mice have normal intestine but are hypersensitive to radiation injury compared to wild-type mice. The intestine in these mice showed loss of Lgr5+ cells, reduced crypt depth and number, and decreased survival after WBI (Saha et al., 2016). These mice were rescued from radiation lethality when treated with conditioned medium from wild-type bone marrow macrophages (BMM) but not with medium from Porcn-null mice BMM.

Furthermore, they have isolated EVs from the BMMconditioned media using ultracentrifugation. These EVs were positive for TSG101, CD9, and Alix. When tested using T-cell factor/lymphoid enhancer factor (TCF/LEF)-luciferase reporter cell line, BMM-EVs showed activation of Wnt signaling. BMMconditioned media improved the survival of mice post-18.5 Gy abdominal radiation. In contrast, the EV depleted media could not rescue, indicating that BMM-EVs carrying Wnt ligands that improve intestinal regeneration after radiation injury.

\section{EVs FOR RADIATION MCM}

The potent anti-inflammatory, anti-fibrotic characteristics of BMMSC-EVs, angiogenic and anti-inflammatory properties of
EC- and M $\phi$-EVs make them promising candidates for regenerative application. The summary of EVs derived from these three cell types that have been discussed in this review on interacting with various signaling molecules is depicted in Figure 3. With such diverse potential, EVs from these cells have been extensively studied for radiation-induced injury. In Table 4, we summarized the potential of BMMSC-, EC- and M $\phi$-EVs in repairing bone marrow, intestine, and lung as discussed in this review.

The success of radiation MCM depends mainly on the efficacy, timing, and dosage of treatment into radiation-damaged tissues. The bio-distribution of EVs in vivo is the crucial driver in the success of MCM and is influenced by the damage model, cell source of EVs, and route of administration. The route of administration of EVs affects biodistribution to various organs (Wiklander et al., 2015). Studies have shown that modification of EVs will influence their biodistribution in vivo (Royo et al., 2020). Therefore, strategies to modify EVs for targeted organ-specific delivery are of great interest for radiation injuries. For example, tissue-specific ECs were known to have specific functions (Rafii et al., 2016). This can be further investigated in terms of EVs from tissue-specific ECs. For instance, lung EC- EVs preferentially distribute to the lung over other tissues providing a lung-targeted therapy.

Alternately, cutting-edge gene-editing technology can be applied to improve or modify the characteristics of EVs. For example, EVs derived from engineered cells overexpressing key growth factors such as Wnt ligands, epidermal growth factor, and fibroblast growth factor could be tested in radiation injury models. Though the overall effect of EVs in radiation-injury models was published, the detailed molecular mechanism of EVs for radiation repair is still not well understood.

\section{EVs for ARS}

Whole-body exposure to high doses of radiation in a short duration leads to the development of ARS, often characterized by damage to hematopoietic, gastrointestinal, and neurovascular systems. It is implacable to conduct a human clinical trial to test radiation MCMs. Instead, FDA has provided "Animal Rule" as guidance for radiation MCM approval. Animal models of the whole body, partial body, or abdominal radiation are often used to develop radiation MCMs for ARS. For treating the acute 


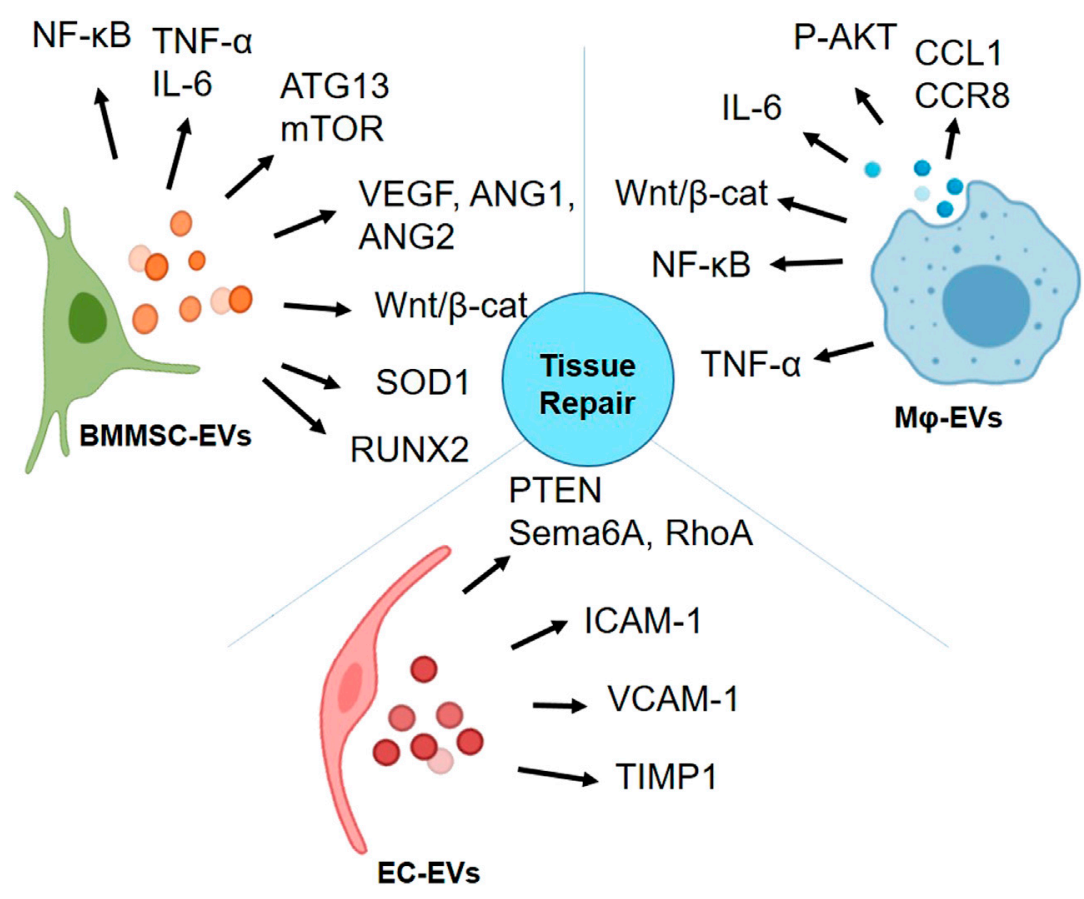

FIGURE 3 | Activation of proteins involved in various signaling pathways by bone marrow mesenchymal stromal/stem cell (BMMSC)-extracellular vesicles (EVs), endothelial cell (EC)-EVs, and macrophage (Mф)-EVs for tissue repair (Graphics adapted from BioRender.com).

effects of radiation during the accidental event, the therapeutic agents may not be accessible immediately. Therefore, evaluating the efficacy of the radiation MCM candidates is set to be administered at least $24 \mathrm{~h}$ after radiation exposure for the first dose. EVs are suitable to develop as radiation MCMs due to their targeted action in a very short duration. However, multiple doses of EVs might be necessary to enhance their efficacy. On the other hand, radiation damage like ARS involves multi-organ failure, and single cell-source derived EVs with specific signaling might not yield a successful recovery. Therefore, a combination of the stem, immune, differentiated, or reprogrammed cell-derived EVs might be necessary for a broader range of efficacy.

\section{EVs for Delayed Effects of Acute Radiation Exposure}

In addition to the acute effects, delayed effects of acute radiation exposure (DEARE) are reported in ARS survivors. Irradiation injury causes DNA damage through free radicals, SSBs, and DSBs. Even though the DNA damage is repaired, the process is not always efficient. The defects in the DNA damage response pathway result in the development of either cell cycle arrest (mitotic catastrophe, senescence) (Li et al., 2018) or cell death (apoptosis, necrosis, and autophagy). Cells in the senescence stage undergo mitotic arrest while being metabolically active. Senescent cells can cause chronic inflammation and disruption of surrounding tissue structure and function via the production of ROS, inflammatory mediators (IL-6, IL-18, and TGF- $\beta$ ), growth factors, and extracellular proteases. This process collectively refers to as senescence-associate secretory phenotype (SASP) (Li et al., 2018). The molecules secreted from SASP can also be packed in EV format (Misawa et al., 2020). This persistent insult from SASP leads to the delayed effect of irradiation-induced senescence, such as fibrosis in the lung (Citrin et al., 2013; He et al., 2019), oral mucositis (IglesiasBartolome et al., 2012), cardiovascular disease (Stewart et al., 2013), hypo-salivation (Peng et al., 2020), hematopoietic cell senescence (Wang et al., 2011). It has also been shown that low radiation can affect the autophagic flux, and activation of autophagy may decrease the senescence induced by radiation and prevent deterioration (Alessio et al., 2015).

Further SASP can lead to radiation-induced bystander effect (RIBE) (Uribe-Etxebarria et al., 2017). RIBE is a condition in which the radiated cells cause a stress response in the neighboring cells resulting in DNA damage, apoptosis, genomic instability, and cell death. Previously cell-to-cell communication of various components of SASP such as IL-6, IL-8, and TGF- $\beta$ were considered as inducers of senescence in neighboring cells. However, the newly emerging focus is that EVs secreted from irradiated cells also played an essential role in modulating senescence in non-irradiated surrounding cells. For example, non-irradiated cells became senescent when treated with EVs isolated from irradiated cells. This observation was made in primary human fibroblasts isolated from neonatal foreskin (Elbakrawy et al., 2020), breast epithelial cancer cells (AlMayah et al., 2015), salivary gland stem/progenitor cells (Peng et al., 2020).

In an in vivo study, the damaged DNA foci were significantly higher in non-irradiated mouse fibroblast cells when treated with 
TABLE 4 | Application of BMMSC-, EC- and macrophage-EVs for organ repair in radiation injury models.

\begin{tabular}{|c|c|c|c|c|c|c|c|c|c|}
\hline $\begin{array}{l}\text { Stromal } \\
\text { Cell } \\
\text { Source }\end{array}$ & $\begin{array}{l}\text { Characteriz- } \\
\text { ation }\end{array}$ & $\begin{array}{l}\text { EV Isolation } \\
\text { method }\end{array}$ & $\begin{array}{c}\text { EV } \\
\text { Characterization }\end{array}$ & $\begin{array}{l}\text { Target } \\
\text { tissue }\end{array}$ & $\begin{array}{l}\text { Model } \\
\text { tested }\end{array}$ & $\begin{array}{c}\text { Route } \\
\text { of } \\
\text { administr- } \\
\text { ation }\end{array}$ & $\begin{array}{l}\text { Dose } \\
\text { of EV }\end{array}$ & Storage & References \\
\hline $\begin{array}{l}\text { Human MSC } \\
\text { (Lonza, MD, } \\
\text { USA \#PT- } \\
\text { 3001) }\end{array}$ & NA & NA & $\begin{array}{l}\text { Average of } 231.3 \pm \\
124.6 \mathrm{~nm}, \mathrm{EM}, \mathrm{WB} \\
\text { for CD9, CD63, } \\
\text { CD81, TSG101, } \\
\text { HSP70 }\end{array}$ & $\begin{array}{l}\text { Bone } \\
\text { marrow }\end{array}$ & $\begin{array}{l}5 \text { Gy WBI in } \\
\text { C57BL/6 } \\
\text { mice }\end{array}$ & Intravenous & $\begin{array}{l}2 \times 10^{8}, 2 \times \\
10^{9} \text { and } 2 \times \\
10^{10} \\
\text { particles/ } \\
\text { mouse }\end{array}$ & $\begin{array}{l}\text { PBS with } 1 \% \\
\text { DMSO, at }-80^{\circ} \mathrm{C}\end{array}$ & $\begin{array}{l}\text { Wen et al. } \\
\text { (2019) }\end{array}$ \\
\hline $\begin{array}{l}\text { Rat bone } \\
\text { marrow }\end{array}$ & $\begin{array}{l}\text { Negative for } \\
\text { CD34, CD45; } \\
\text { Positive for } \\
\text { CD29, CD44 } \\
\text { and CD90 }\end{array}$ & $\begin{array}{l}\text { Differential } \\
\text { centrifugation }\end{array}$ & $\begin{array}{l}\text { EM, WB CD63, } \\
\text { CD81; Negative for } \\
\text { Calnexin }\end{array}$ & $\begin{array}{l}\text { Bone } \\
\text { marrow }\end{array}$ & $\begin{array}{l}16 \text { Gy Knee } \\
\text { joint } \\
\text { irradiated } \\
\text { Sprague- } \\
\text { Dawley Rats }\end{array}$ & Intravenous & 1.6 mg/kg & $\mathrm{PBS}$, at $-80^{\circ} \mathrm{C}$ & $\begin{array}{l}\text { Zuo et al. } \\
\text { (2019) }\end{array}$ \\
\hline $\begin{array}{l}\text { Murine and } \\
\text { human bone } \\
\text { marrow }\end{array}$ & $\begin{array}{l}\text { Negative for } \\
\text { CD31, CD45, } \\
\text { CD11b, CD34 } \\
\text { and CD86; } \\
\text { Positive for } \\
\text { CD44, CD29, } \\
\text { CD105, Sca-1 }\end{array}$ & $\begin{array}{l}\text { Differential } \\
\text { centrifugation }\end{array}$ & $\begin{array}{l}\text { NanosightNS500, } \\
\text { EM, WB for CD9, } \\
\text { CD63, CD81 }\end{array}$ & $\begin{array}{l}\text { Bone } \\
\text { marrow }\end{array}$ & $\begin{array}{l}2,5 \text { and } \\
9.5 \text { Gy } \\
\text { Cesium WBI }\end{array}$ & Intravenous & $\begin{array}{l}4 \times 10^{9} \\
\text { particles/ } \\
\text { mouse }\end{array}$ & $\begin{array}{l}10 \% \text { DMSO, at } \\
-80^{\circ} \mathrm{C} \text { for } \\
6 \text { months }\end{array}$ & $\begin{array}{l}\text { Wen et al. } \\
\text { (2016) }\end{array}$ \\
\hline $\begin{array}{l}\text { Immortalized } \\
\text { E1-MYC } 16.3 \\
\text { human } \\
\text { embryonic } \\
\text { stem cells }\end{array}$ & $\begin{array}{l}\text { Negative for } \\
\text { CD45; Positive } \\
\text { for CD73, } \\
\text { CD105 }\end{array}$ & $\begin{array}{l}\text { Tangential } \\
\text { flow filtration }\end{array}$ & $<200$ nm, EM & Intestine & $\begin{array}{l}\text { WBI in nude } \\
\text { mice }\end{array}$ & Intra-venous & $\begin{array}{l}600 \mu \mathrm{g} \text { of EV, } \\
6 \mathrm{~h}, 24 \mathrm{~h}, \text { and } \\
48 \mathrm{~h} \\
\text { post-WBI }\end{array}$ & $\begin{array}{l}\text { Paracrine } \\
\text { Therapeutics's- } \\
\text { Proprietary } \\
\text { technique, } \\
\text { stored at }-20^{\circ} \mathrm{C}\end{array}$ & $\begin{array}{l}\text { Accarie et al. } \\
(2020)\end{array}$ \\
\hline $\begin{array}{l}\text { Mouse bone } \\
\text { marrow } \\
\text { endothelial } \\
\text { cells }\end{array}$ & NA & $\begin{array}{l}\text { Differential } \\
\text { centrifugation }\end{array}$ & $\begin{array}{l}<200 \mathrm{~nm} \text {; WB for } \\
\text { CD31, VE- } \\
\text { cadherin; EM }\end{array}$ & $\begin{array}{l}\text { Bone } \\
\text { marrow }\end{array}$ & $\begin{array}{l}5 \text { and } 8 \text { Gy } \\
\text { Cesium WBI }\end{array}$ & $\begin{array}{l}\text { four days } \\
\text { i.v., starting } \\
24 \mathrm{~h} \\
\text { post-WBI }\end{array}$ & $\begin{array}{l}1.9 \times 10^{9} \\
\text { particles of } \\
\text { EV per } \\
\text { injection }\end{array}$ & NA & $\begin{array}{l}\text { Piryani et al. } \\
(2019)\end{array}$ \\
\hline $\begin{array}{l}\text { Mouse bone } \\
\text { marrow } \\
\text { macrophages }\end{array}$ & $\begin{array}{l}\text { Positive for } \\
\text { CD11b }\end{array}$ & $\begin{array}{l}\text { Differential } \\
\text { centrifugation }\end{array}$ & $\begin{array}{l}\text { WB for CD9, } \\
\text { TSG101, Alix }\end{array}$ & Intestine & $\begin{array}{l}18.5 \text { Gy } \\
\text { Abdominal } \\
\text { Irradiation }\end{array}$ & Intra-venous & $\begin{array}{l}500 \mu \mathrm{l} \text { of EV } \\
\text { and } \\
\text { conditioned } \\
\text { media }\end{array}$ & NA & $\begin{array}{l}\text { Saha et al. } \\
\text { (2016) }\end{array}$ \\
\hline
\end{tabular}

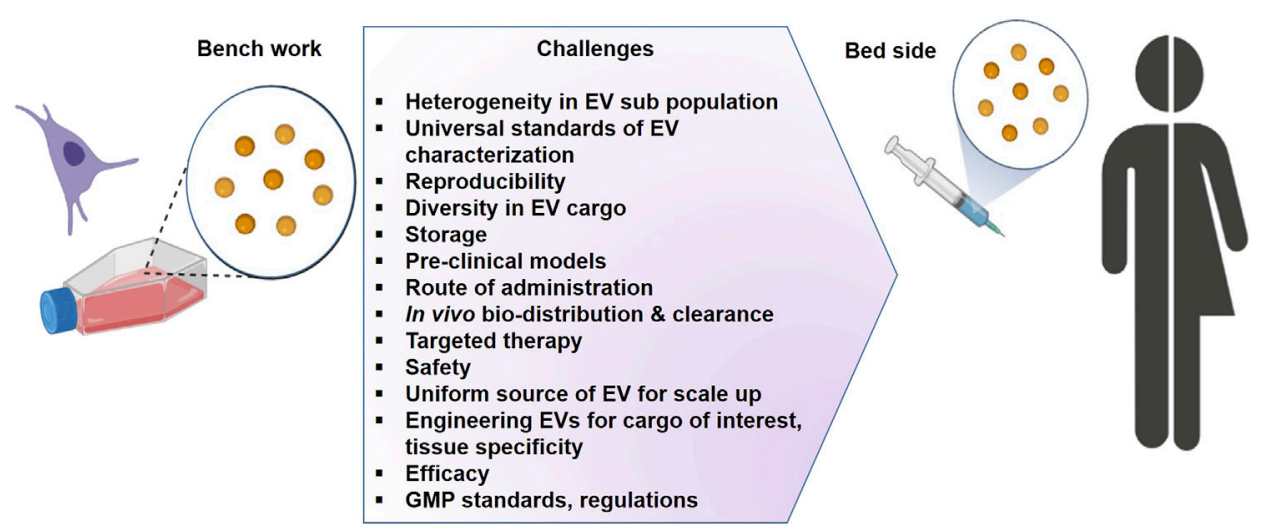

FIGURE 4 | The challenges for the development of extracellular vesicles as therapeutics (Graphic adapted from BioRender.com).

the irradiated mouse's serum-EVs than non-irradiated mouse serum-EVs (Ariyoshi et al., 2019). In another study, downregulation of antioxidant enzyme genes and cellular redox system (iNOS2) genes was observed in non-irradiated mice as a bystander effect when injected with bone marrow-EVs from irradiated mice (Hargitai et al., 2021). In the same token, recent evidence suggests that EVs as SASP, secreted from senescent cells might contribute to tumorigenesis and age-associated pathologies (Misawa et al., 2020). It can be a potential mechanism to explain a high incidence of cancer developed in the survivors after radiation exposure.

Senescent cells can be targeted for therapeutic purposes, i.e., via senolytic drugs. These drugs are usually small 
molecules that can selectively remove senescent cells. In comparison, senolytics can be used as MCMs for DEARE such as fibrosis.

The research for developing MSCs or MSC-EVs as senolytics is limited. MSC therapy alleviates irradiation-induced bronchial-alveolar epithelial cellular senescence and inhibits the secretion of SASP factors such as the chemokine (C-C motif) ligand 2 (CCL2) and urokinase-type plasminogen activator (Plau/uPA). In this study, aortic MSC and BMMSCs were administered at 0.5 million cells $24 \mathrm{~h}$ after irradiation (Klein et al., 2016). Similarly, EVs from the human placenta MSC reduced the senescence in the ECs after whole thoracic radiation. The miRNA-214-3p from EVs inhibited the Ataxia telangiectasia mutated signaling pathway of senescence in ECs and further downregulated the expression of SASP factors, resulting in attenuation of fibrosis (Lei et al., 2020). Therefore, MSC-EVs have the potential to act as senolytics, further reducing the DEARE injury in normal cells.

\section{CHALLENGES IN DEVELOPING EVs FOR CLINICAL USE}

\section{Characterization and Production}

EVs are classified based on immunolabeling of EV surface proteins such as tetraspanins, integrins, cell adhesion molecules, and growth factor receptors (Lotvall et al., 2014; Buzas et al., 2018). The heterogeneity in size and content of the EV populations makes it challenging to purify a single EV population (Kowal et al., 2016). Therefore, the basic understanding of the size, either with dynamic light scatteringbased techniques or electron microscopy; immunolabeling with markers such as CD63 and CD9 are necessary for the characterization of the EV population of interest. EVs produced by even a single cell type have subpopulations within; therefore, more numbers of surface markers need to be analyzed. An antibody array such as Exo-CheckTM (System Biosciences) measures up to 8 surface markers expressed on EVs in a single sample is advantageous. Using immortalized stable cell lines as a source of EVs can be a way to obtain pure, sub-population-specific EVs. Alternately, methods that can design and control the cargo in EVs, such as genetically engineered cell lines, will promote EVs as drug delivery systems with a targeted action (Luan et al., 2017).

Studies that report specific cell-derived EVs should include the passage number of cells, seeding density, and culture conditions, which are essential parameters affecting the production and characteristics of EVs. Also, the dose of EVs used in preclinical models is often represented as micrograms of protein or particle number in some studies. Though particle concentration seems to be an ideal reference, such state-ofthe-art facilities measuring particle number and concentration of EVs are not always available in every research laboratory. The number of EVs obtained from 1 million mouse BMMSCs under specific culture conditions might differ among each laboratory. Therefore, additional information as mentioned in Tables 1-4 will help researchers compare their results. Also, it will expand our knowledge on the average EV production potential of different cell types under specific culture conditions.

EVs derived from specific cell types interact with distinct signaling molecules, as described in Figure 3. Therefore, knowledge of various signaling pathways that specific cell-EVs can modulate is a prerequisite for developing targeted therapies. Luciferase reporter constructs containing specific promoter response elements are used to generate stable cell lines to monitor the activity of the transcription factors. Upon addition of specific ligands or test compounds with predicted activation, reporter activity can be measured by adding a lightemitting-substrate for the quantification. For example, HEK293 cells having TCF/LEF luciferase reporter construct have been used to monitor the Wnt activation by mouse BMM-EVs (McBride et al., 2017). Similarly, NF- $\kappa B$ reporter cells have been treated with MSC-EVs, and their increase in luminescence has been detected for NF- $\kappa \mathrm{B}$ activation (Goloviznina et al., 2016). Similar luciferase-reporter cell lines for the notch, hedgehog, and Wnt signaling are commercially available (Accegen) to test whether specific cell-derived EVs can stimulate these singling pathways. Further, various platforms such as nCounter ${ }^{\circledR}$-Stem Cell Characterization Panel (NanoString Technologies), that contain a panel of around 770 genes is available to evaluate stem cell viability and functionality. Such platforms need to be developed for screening the potential of biomolecules present in EVs. Alternately, conventional proteomics and miRNA sequencing are also available for detailed cargo profiling in the EVs of interest.

The small size and short life span of EVs make it more challenging to track them in vivo; however, ex vivo membrane labeling of EVs or labeled EVs (CD63-GFP) from reporter-cell lines or mice (Luo et al., 2020) are an alternate. Tracking EVs with these strategies will reveal their bio-distribution in vivo and help design better dosing strategies to target radiation-induced injury.

In situations such as accidental exposure to radiation (DiCarlo et al., 2017), the EVs need to be administered within $24-48 \mathrm{~h}$ to rescue bone marrow. In such a scenario, scaled-up and cryopreserved EVs should to be available to the patients in a short period of time. Therefore, EV-biobanks operated with clinical good manufacturing practice (cGMP) standards under FDA regulations are necessary to support the development of EVtherapeutics.

Biogenesis of EVs is a cellular response to physiological stimuli; therefore, in vitro culture conditions and treatments such as growth factors can influence the quantitative and qualitative production of EVs. For instance, serum-free culture or usage of exosome-free serum is often used to culture cells for $\mathrm{EV}$ production, which might alter the natural EV production threshold. On the other hand, parameters such as $\mathrm{pH}$, temperature, and cryopreservation conditions can alter the EV uptake by cells (Cheng et al., 2019). Therefore, optimization of these parameters is needed to improve the purity and yield of EVs and their efficacy.

\section{Standardization}

Heterogeneity in the EV sub-populations poses them as challenging for developing as therapeutics. Simultaneously, 
their diversity in containing various protein, nucleic acid, and lipid in the cargo makes them attractive for targeted delivery with multi-functional activity. Thorough characterization of EVs according to MISEV guidelines and reproducibility in the generation of EVs of interest is essential. GMP grade methodologies for EV preparation need to be developed for clinical translation. To further develop EVs as radiation MCM, the quality of cell source, cell culture, and method of EV preparation need to be standardized and reproducible across respective fields, followed by the in vitro and in vivo functionality assessment.

With the growing interest in the EVs for research and for clinical use, it is extremely important for universally acceptable methods and standards. ISEV community and its tools such as EV-TRACK and EV-METRIC are supporting EV-based research laboratories with centralized knowledge of EVs (Van Deun et al., 2017) (Royo et al., 2020). Researchers can submit their experimental data related to the method of isolation, characterization, and analysis from their projects to obtain constructive input and validation from EV-TRACK. In addition, workshops, conferences, and interactive scientific discussions organized by ISEV are enhancing the collaborative network of the EV research community, share, expand the knowledge between research laboratories around the globe, and collectively troubleshoot the challenges in EV research.

\section{Expansion}

Large-scale production of EVs is dependent on the type of cell source and method of isolation. Scaling up from T-flasks to bioreactors can increase the production of EVs. However, these changes in the culturing environment might influence cells and thereby change the characteristics of EVs. Therefore, these parameters need to be standardized in the scale-up process. The quality of EVs and their bioactivity need to be confirmed after the scale-up. Methods of EV isolation include but are not limited to differential/density-gradient ultracentrifugation, tangential flow filtration, bind/elute chromatography, sizespecific separation, and immunolabeling-based EV selection. There is a unique principle and advantage for each of these methods. Ultracentrifugation is the most popularly used (Royo et al., 2020) and considered the gold standard; however, it might not be suitable for the purification of EVs on a large scale. Therefore, a combination of techniques might be an alternate strategy to obtain pure EVs.

\section{Storage}

Another major challenge in $\mathrm{EV}$ research is their storage. Literature suggests storing EVs at $+4^{\circ} \mathrm{C}$ for a few weeks. EVs can be stored long-term at $-80^{\circ} \mathrm{C}$ either in PBS or with cryoprotectants such as DMSO, Trehalose (Bosch et al., 2016), and glycerol (Jeyaram and Jay, 2017). For cryopreservation of various cell types, commercial reagents such as CryoStor, and NutriFreez are available. More GMP suitable cryopreservation reagents need to be developed for EV preservation. On other hand freeze-dried EVs can be a greater source for long-term storage and therapeutic applications (El Baradie et al., 2020).

\section{Safety and Side Effects}

In cell transplant studies, the in vivo microenvironment signals might influence viability, proliferation, and functionality of the transplanted cells. This might not be an issue in EV therapeutics since they do not replicate or differentiate and are short-lived. However, EVs that are naturally produced by a cell type are not necessarily specific to one tissue. Also, the multi-factorial bioactivity of EVs might cause side effects, a safety concern for targeted therapy. Another function of EVs secreted from the cells is a self-defense mechanism to maintain cellular homeostasis by removing the toxic molecules from the cells (Wallis et al., 2020).

To enhance a more targeted approach and minimize side effects, EVs can be locally administered to a specific tissue, such as intra-glandular injections at the site of injury. Alternately, engineered cells that produce tissue-specific EVs could be used.

EVs obtained from genetically engineered and immortalized cell lines might differ from naturally occurring EVs. Therefore, they need to be verified for purity, characterization, mechanism of action, in vivo biodistribution, and bioactivity. Genetically engineered cell-derived EVs might carry oncogenic remnants; therefore, they need to be verified for immunogenic and tumorigenic side effects.

There is a growing interest in using EVs as natural drugdelivery vehicles. Physical and chemical methods are used for drug-loading into the EVs. Hence, any immunogenic effect arising from these methodologies in the processing of EVs needs to be verified.

Overall, EVs are no exception with respect to having safety regulations for therapeutic application. Aspects such as production methods, purification, dosing, storage, and administration are important to check points for safe EV therapeutics.

\section{CONCLUSION}

An overview of the literature clearly indicates that research on EVs suffers from limitations. A number of technical points remain to be urgently clarified as summarized in Figure 4. However, the complexity of EVs heterogeneity and functions has to be taken into account. One of the most urgent challenges is to set up methods to characterize separately each kind of EVs in order to precisely define their individual cargoes and functions. The first challenge is how to define and measure EVs in a reproducible manner, their large scale production and purification for their use in case of mass casualties. In addition, understanding the molecular mechanisms governing EV formation, release, and clearance, as well as those involved in cell-cell communication, will enable us to envision new therapeutic strategies for favoring tissue repair. As described in this review several biological features provide EVs as an attractive tool for regenerative medicine. The advancement of translational research directed toward treating battlefield injury will have multiple cross over opportunities for their applications within the population. They will surely be a part of innovative therapeutic interventions as soon as few technical barriers are solved. 
The adaptability of BMMSC-, EC- and M $\phi$-derived EVs exhibit a remarkable capacity to adapt to the requirements of the damaged tissue in which the vesicles integrate and provide a promising option to address for the medical field after radiation exposure and complication of radiotherapy in order to support a personalized treatment. MSC therapy has established an extensive safety profile in the clinical setting and compared to the other cell types such as the endothelial progenitor cells, they present important advantage related to their isolation, culture and high scale production. Thus, in case of a radiological or nuclear event, the use of MSC-EV approach will provide a promising option to address the unmet needs that are critically important in the medical management of mass casualties.

\section{REFERENCES}

Accarie, A., l'Homme, B., Benadjaoud, M. A., Lim, S. K., Guha, C., Benderitter, M., et al. (2020). Extracellular Vesicles Derived from Mesenchymal Stromal Cells Mitigate Intestinal Toxicity in a Mouse Model of Acute Radiation Syndrome. Stem Cel Res Ther. 11 (1), 371. doi:10.1186/s13287020-01887-1

Acharya, M. M., Rosi, S., Jopson, T., and Limoli, C. L. (2015). Human Neural Stem Cell Transplantation Provides Long-Term Restoration of Neuronal Plasticity in the Irradiated hippocampus. Cel Transpl. 24 (4), 691-702. doi:10.3727/ 096368914X684600

Al-Mayah, A., Bright, S., Chapman, K., Irons, S., Luo, P., Carter, D., et al. (2015). The Non-targeted Effects of Radiation Are Perpetuated by Exosomes. Mutat. Research/Fundamental Mol. Mech. Mutagenesis 772, 38-45. doi:10.1016/j. mrfmmm.2014.12.007

Alcayaga-Miranda, F., Varas-Godoy, M., and Khoury, M. (2016). Harnessing the Angiogenic Potential of Stem Cell-Derived Exosomes for Vascular Regeneration. Stem Cell Int. 2016, 1-11. doi:10.1155/2016/3409169

Alessio, N., Del Gaudio, S., Capasso, S., Di Bernardo, G., Cappabianca, S., Cipollaro, M., et al. (2015). Low Dose Radiation Induced Senescence of Human Mesenchymal Stromal Cells and Impaired the Autophagy Process. Oncotarget 6 (10), 8155-8166. doi:10.18632/oncotarget.2692

Andrews, A. M., and Rizzo, V. (2016). Microparticle-Induced Activation of the Vascular Endothelium Requires Caveolin-1/Caveolae. PLoS One 11 (2), e0149272. doi:10.1371/journal.pone.0149272

Ariyoshi, K., Miura, T., Kasai, K., Fujishima, Y., Nakata, A., and Yoshida, M. (2019). Radiation-Induced Bystander Effect Is Mediated by Mitochondrial DNA in Exosome-like Vesicles. Sci. Rep. 9 (1), 9103. doi:10.1038/s41598019-45669-z

Asfaha, S., Hayakawa, Y., Muley, A., Stokes, S., Graham, T. A., Ericksen, R. E., et al. (2015). Krt19+/Lgr5- Cells Are Radioresistant Cancer-Initiating Stem Cells in the Colon and Intestine. Cell Stem Cell 16 (6), 627-638. doi:10.1016/j.stem.2015. 04.013

Bai, S., Yin, Q., Dong, T., Dai, F., Qin, Y., Ye, L., et al. (2020). Endothelial Progenitor Cell-Derived Exosomes Ameliorate Endothelial Dysfunction in a Mouse Model of Diabetes. Biomed. Pharmacother. 131, 110756. doi:10.1016/j. biopha.2020.110756

Barker, N., van Es, J. H., Kuipers, J., Kujala, P., van den Born, M., Cozijnsen, M., et al. (2007). Identification of Stem Cells in Small Intestine and Colon by Marker Gene Lgr5. Nature 449 (7165), 1003-1007. doi:10.1038/nature06196

Becker, A. J., McCULLOCH, E. A., and Till, J. E. (1963). Cytological Demonstration of the Clonal Nature of Spleen Colonies Derived from Transplanted Mouse Marrow Cells. Nature 197, 452-454. doi:10.1038/ $197452 \mathrm{a} 0$

Benderitter, M., Caviggioli, F., Chapel, A., Coppes, R. P., Guha, C., Klinger, M., et al. (2014). Stem Cell Therapies for the Treatment of Radiation-Induced Normal Tissue Side Effects. Antioxid. Redox Signaling 21 (2), 338-355. doi:10. 1089/ars.2013.5652

\section{AUTHOR CONTRIBUTIONS}

LN, W-LY, RT, and CG conceptualized the content of the manuscript. LN initiated the draft, and PD contributed several sections. LN, PD, and W-LY edited and revised the manuscript. RT and CG revised and supervised the completion of the manuscript.

\section{FUNDING}

This work is supported by the US National Institute of Health (NIH) grants U01AI38324, U01AI133608, and U01DK103155 (to CG), and U01AI133655 (to W-LY).

Berger, C. N., Crepin, V. F., Roumeliotis, T. I., Wright, J. C., Carson, D., PevsnerFischer, M., et al. (2017). Citrobacter Rodentium Subverts ATP Flux and Cholesterol Homeostasis in Intestinal Epithelial Cells In Vivo. Cel Metab. 26 (5), 738-752. doi:10.1016/j.cmet.2017.09.003

Bosch, S., de Beaurepaire, L., Allard, M., Mosser, M., Heichette, C., Chrétien, D. et al. (2016). Trehalose Prevents Aggregation of Exosomes and Cryodamage. Sci. Rep. 6, 36162. doi:10.1038/srep36162

Bouchareychas, L., Duong, P., Covarrubias, S., Alsop, E., Phu, T. A., Chung, A., et al. (2020). Macrophage Exosomes Resolve Atherosclerosis by Regulating Hematopoiesis and Inflammation via MicroRNA Cargo. Cel Rep. 32 (2), 107881. doi:10.1016/j.celrep.2020.107881

Boulter, L., Lu, W.-Y., and Forbes, S. J. (2013). Differentiation of Progenitors in the Liver: a Matter of Local Choice. J. Clin. Invest. 123 (5), 1867-1873. doi:10.1172/ JCI66026

Boyer, M. J., Kimura, Y., Akiyama, T., Baggett, A. Y., Preston, K. J., Scalia, R., et al. (2020). Endothelial Cell-derived Extracellular Vesicles Alter Vascular Smooth Muscle Cell Phenotype through High-mobility Group Box Proteins. J. Extracellular Vesicles 9 (1), 1781427. doi:10.1080/20013078. 2020.1781427

Buzás, E. I., Tóth, E. Á., Sódar, B. W., and Szabó-Taylor, K. É. (2018). Molecular Interactions at the Surface of Extracellular Vesicles. Semin. Immunopathol 40 (5), 453-464. doi:10.1007/s00281-018-0682-0

Caplan, A. I., and Dennis, J. E. (2006). Mesenchymal Stem Cells as Trophic Mediators. J. Cel. Biochem. 98 (5), 1076-1084. doi:10.1002/jcb.20886

Cheng, Y., Zeng, Q., Han, Q., and Xia, W. (2019). Effect of pH, Temperature and Freezing-Thawing on Quantity Changes and Cellular Uptake of Exosomes. Protein Cell 10 (4), 295-299. doi:10.1007/s13238-018-0529-4

Chu, C., Gao, Y., Lan, X., Lin, J., Thomas, A. M., and Li, S. (2020). Stem-Cell Therapy as a Potential Strategy for Radiation-Induced Brain Injury. Stem Cel Rev Rep. 16 (4), 639-649. doi:10.1007/s12015-020-09984-7

Chute, J. P., Muramoto, G. G., Salter, A. B., Meadows, S. K., Rickman, D. W., Chen, B., et al. (2007). Transplantation of Vascular Endothelial Cells Mediates the Hematopoietic Recovery and Survival of Lethally Irradiated Mice. Blood 109 (6), 2365-2372. doi:10.1182/blood-2006-05-022640

Citrin, D. E., Shankavaram, U., Horton, J. A., Shield, W., 3rd, Zhao, S., Asano, H., et al. (2013). Role of Type II Pneumocyte Senescence in Radiation-Induced Lung Fibrosis. J. Natl. Cancer Inst. 105 (19), 1474-1484. doi:10.1093/jnci/djt212

Coppes, R., and Stokman, M. (2011). Stem Cells and the Repair of RadiationInduced Salivary Gland Damage. Oral Dis. 17 (2), 143-153. doi:10.1111/j.16010825.2010.01723.x

Dai, Y., Wang, S., Chang, S., Ren, D., Shali, S., Li, C., et al. (2020). M2 MacrophageDerived Exosomes Carry microRNA-148a to Alleviate Myocardial Ischemia/ reperfusion Injury via Inhibiting TXNIP and the TLR4/NF-Kb/nlrp3 Inflammasome Signaling Pathway. J. Mol. Cell Cardiol. 142, 65-79. doi:10. 1016/j.yjmcc.2020.02.007

Davidson, S. M., Riquelme, J. A., Zheng, Y., Vicencio, J. M., Lavandero, S., and Yellon, D. M. (2018). Endothelial Cells Release Cardioprotective Exosomes that May Contribute to Ischaemic Preconditioning. Sci. Rep. 8 (1), 15885. doi:10. 1038/s41598-018-34357-z 
de Godoy, M. A., Saraiva, L. M., de Carvalho, L. R. P., Vasconcelos-Dos-Santos, A., Beiral, H. J. V., Ramos, A. B., et al. (2018). Mesenchymal Stem Cells and CellDerived Extracellular Vesicles Protect Hippocampal Neurons from Oxidative Stress and Synapse Damage Induced by Amyloid- $\beta$ Oligomers. J. Biol. Chem. 293 (6), 1957-1975. doi:10.1074/jbc.M117.807180

DiCarlo, A. L., Tamarat, R., Rios, C. I., Benderitter, M., Czarniecki, C. W., Allio, T. C., et al. (2017). Cellular Therapies for Treatment of Radiation Injury: Report from a NIH/NIAID and IRSN Workshop. Radiat. Res. 188 (2), e54-e75. doi:10. $1667 /$ RR14810.1

Dominici, M., Le Blanc, K., Mueller, I., Slaper-Cortenbach, I., Marini, F. C., Krause, D. S., et al. (2006). Minimal Criteria for Defining Multipotent Mesenchymal Stromal Cells. The International Society for Cellular Therapy Position Statement. Cytotherapy 8 (4), 315-317. doi:10.1080/14653240600855905

Dong, L.-H., Jiang, Y.-Y., Liu, Y.-J., Cui, S., Xia, C.-C., Qu, C., et al. (2015). The Anti-fibrotic Effects of Mesenchymal Stem Cells on Irradiated Lungs via Stimulating Endogenous Secretion of HGF and PGE2. Sci. Rep. 5, 8713. doi:10.1038/srep08713

El Baradie, K. B. Y., Nouh, M., O’Brien III, F., Iii, Liu, Y., Fulzele, S., Eroglu, A., et al. (2020). Freeze-Dried Extracellular Vesicles from Adipose-Derived Stem Cells Prevent Hypoxia-Induced Muscle Cell Injury. Front. Cel Dev. Biol. 8, 181. doi:10.3389/fcell.2020.00181

Elbakrawy, E., Kaur Bains, S., Bright, S., Al-Abedi, R., Mayah, A., Goodwin, E., et al. (2020). Radiation-Induced Senescence Bystander Effect: The Role of Exosomes. Biology 9 (8), 191. doi:10.3390/biology9080191

Ferguson, S. W., Wang, J., Lee, C. J., Liu, M., Neelamegham, S., Canty, J. M., et al. (2018). The microRNA Regulatory Landscape of MSC-Derived Exosomes: a Systems View. Sci. Rep. 8 (1), 1419. doi:10.1038/s41598-018-19581-x

Flamant, S., and Tamarat, R. (2016). Extracellular Vesicles and Vascular Injury: New Insights for Radiation Exposure. Radiat. Res. 186 (2), 203-218. doi:10. 1667/RR14482.1

Follenzi, A., Benten, D., Novikoff, P., Faulkner, L., Raut, S., and Gupta, S. (2008). Transplanted Endothelial Cells Repopulate the Liver Endothelium and Correct the Phenotype of Hemophilia A Mice. J. Clin. Invest. 118 (3), 935-945. doi:10. 1172/JCI32748

Friedenstein, A. J., Petrakova, K. V., Kurolesova, A. I., and Frolova, G. P. (1968). Heterotopic Transplants of Bone Marrow. Transplantation 6 (2), 230-247. doi:10.1097/00007890-196803000-00009

Gao, B., Zhou, S., Sun, C., Cheng, D., Zhang, Y., Li, X., et al. (2020). Brain Endothelial Cell-Derived Exosomes Induce Neuroplasticity in Rats with Ischemia/Reperfusion Injury. ACS Chem. Neurosci. 11 (15), 2201-2213. doi:10.1021/acschemneuro.0c00089

Gatti, S., Bruno, S., Deregibus, M. C., Sordi, A., Cantaluppi, V., Tetta, C., et al. (2011). Microvesicles Derived from Human Adult Mesenchymal Stem Cells Protect against Ischaemia-Reperfusion-Induced Acute and Chronic Kidney Injury. Nephrol. Dial. Transplant. 26 (5), 1474-1483. doi:10.1093/ndt/gfr015

Ghobadi, G., Bartelds, B., van der Veen, S. J., Dickinson, M. G., Brandenburg, S., Berger, R. M. F., et al. (2012). Lung Irradiation Induces Pulmonary Vascular Remodelling Resembling Pulmonary Arterial Hypertension. Thorax 67 (4), 334-341. doi:10.1136/thoraxjnl-2011-200346

Giuranno, L., Ient, J., De Ruysscher, D., and Vooijs, M. A. (2019). RadiationInduced Lung Injury (RILI). Front. Oncol. 9, 877. doi:10.3389/fonc.2019.00877

Goloviznina, N. A., Verghese, S. C., Yoon, Y. m., Taratula, O., Marks, D. L., and Kurre, P. (2016). Mesenchymal Stromal Cell-Derived Extracellular Vesicles Promote Myeloid-Biased Multipotent Hematopoietic Progenitor Expansion via Toll-like Receptor Engagement. J. Biol. Chem. 291 (47), 24607-24617. doi:10. 1074/jbc.M116.745653

Gong, W., Guo, M., Han, Z., Wang, Y., Yang, P., Xu, C., et al. (2016). Mesenchymal Stem Cells Stimulate Intestinal Stem Cells to Repair Radiation-Induced Intestinal Injury. Cell Death Dis. 7 (9), e2387. doi:10.1038/cddis.2016.276

Grange, C., Tritta, S., Tapparo, M., Cedrino, M., Tetta, C., Camussi, G., et al. (2019). Stem Cell-Derived Extracellular Vesicles Inhibit and Revert Fibrosis Progression in a Mouse Model of Diabetic Nephropathy. Sci. Rep. 9 (1), 4468. doi:10.1038/s41598-019-41100-9

Green, D. E., and Rubin, C. T. (2014). Consequences of Irradiation on Bone and Marrow Phenotypes, and its Relation to Disruption of Hematopoietic Precursors. Bone 63, 87-94. doi:10.1016/j.bone.2014.02.018

Guha, C., Sharma, A., Gupta, S., Alfieri, A., Gorla, G. R., Gagandeep, S., et al. (1999). Amelioration of Radiation-Induced Liver Damage in Partially
Hepatectomized Rats by Hepatocyte Transplantation. Cancer Res. 59 (23), 5871-5874.

Hargitai, R., Kis, D., Persa, E., Szatmári, T., Sáfrány, G., and Lumniczky, K. (2021). Oxidative Stress and Gene Expression Modifications Mediated by Extracellular Vesicles: An In Vivo Study of the Radiation-Induced Bystander Effect. Antioxidants 10 (2), 156. doi:10.3390/antiox10020156

He, Y., Thummuri, D., Zheng, G., Okunieff, P., Citrin, D. E., Vujaskovic, Z., et al. (2019). Cellular Senescence and Radiation-Induced Pulmonary Fibrosis. Translational Res. 209, 14-21. doi:10.1016/j.trsl.2019.03.006

Herrera, M. B., Fonsato, V., Gatti, S., Deregibus, M. C., Sordi, A., Cantarella, D., et al. (2010). Human Liver Stem Cell-derived Microvesicles Accelerate Hepatic Regeneration in Hepatectomized Rats. J. Cell Mol. Med. 14 (6B), 1605-1618. doi:10.1111/j.1582-4934.2009.00860.x

Horton, J. A., Hudak, K. E., Chung, E. J., White, A. O., Scroggins, B. T., Burkeen, J. F., et al. (2013). Mesenchymal Stem Cells Inhibit Cutaneous RadiationInduced Fibrosis by Suppressing Chronic Inflammation. Stem Cells 31 (10), 2231-2241. doi:10.1002/stem.1483

Iglesias-Bartolome, R., Patel, V., Cotrim, A., Leelahavanichkul, K., Molinolo, A. A., Mitchell, J. B., et al. (2012). mTOR Inhibition Prevents Epithelial Stem Cell Senescence and Protects from Radiation-Induced Mucositis. Cell Stem Cell 11 (3), 401-414. doi:10.1016/j.stem.2012.06.007

Jeyaram, A., and Jay, S. M. (2017). Preservation and Storage Stability of Extracellular Vesicles for Therapeutic Applications. AAPS J. 20 (1), 1. doi:10.1208/s12248-017-0160-y

Kabarriti, R., Brodin, N. P., Maron, M. I., Tomé, W. A., Halmos, B., Guha, C., et al. (2020). Extent of Prior Lung Irradiation and Mortality in COVID-19 Patients with a Cancer History. Adv. Radiat. Oncol. 5 (4), 707-710. doi:10.1016/j.adro. 2020.04.028

Kabarriti, R., Zhou, H., Vainshtein, J. V., Saha, S., Hannan, R., Thawani, N., et al. (2010). Transplantation of Liver Sinusoidal Endothelial Cells Repairs HIR Induced Hepatic Endothelial Cell Damage. Int. J. Radiat. Oncology ${ }^{*}$ Biology ${ }^{*}$ Physics 78 (3), S41. doi:10.1016/j.ijrobp.2010.07.131

Kabat, M., Bobkov, I., Kumar, S., and Grumet, M. (2020). Trends in Mesenchymal Stem Cell Clinical Trials 2004-2018: Is Efficacy Optimal in a Narrow Dose Range?. Stem Cell Transl Med 9 (1), 17-27. doi:10.1002/sctm.19-0202

Kim, H., Wang, S. Y., Kwak, G., Yang, Y., Kwon, I. C., and Kim, S. H. (2019). Exosome-Guided Phenotypic Switch of M1 to M2 Macrophages for Cutaneous Wound Healing. Adv. Sci. 6 (20), 1900513. doi:10.1002/advs. 201900513

Klein, D., Schmetter, A., Imsak, R., Wirsdörfer, F., Unger, K., Jastrow, H., et al. (2016). Therapy with Multipotent Mesenchymal Stromal Cells Protects Lungs from Radiation-Induced Injury and Reduces the Risk of Lung Metastasis. Antioxid. Redox Signaling 24 (2), 53-69. doi:10.1089/ars. 2014.6183

Klein, D., Steens, J., Wiesemann, A., Schulz, F., Kaschani, F., Röck, K., et al. (2017). Mesenchymal Stem Cell Therapy Protects Lungs from Radiation-Induced Endothelial Cell Loss by Restoring Superoxide Dismutase 1 Expression. Antioxid. Redox Signaling 26 (11), 563-582. doi:10.1089/ars.2016.6748

Kojima, T., Kanemaru, S.-i., Hirano, S., Tateya, I., Ohno, S., Nakamura, T., et al. (2011). Regeneration of Radiation Damaged Salivary Glands with AdiposeDerived Stromal Cells. The Laryngoscope 121 (9), 1864-1869. doi:10.1002/lary. 22080

Komaki, M., Numata, Y., Morioka, C., Honda, I., Tooi, M., Yokoyama, N., et al. (2017). Exosomes of Human Placenta-Derived Mesenchymal Stem Cells Stimulate Angiogenesis. Stem Cel Res Ther 8 (1), 219. doi:10.1186/s13287017-0660-9

Kowal, J., Arras, G., Colombo, M., Jouve, M., Morath, J. P., Primdal-Bengtson, B., et al. (2016). Proteomic Comparison Defines Novel Markers to Characterize Heterogeneous Populations of Extracellular Vesicle Subtypes. Proc. Natl. Acad. Sci. USA 113 (8), E968-E977. doi:10.1073/pnas.1521230113

Kulkarni, S., Wang, T. C., and Guha, C. (2016). Stromal Progenitor Cells in Mitigation of Non-hematopoietic Radiation Injuries. Curr. Pathobiol Rep. 4 (4), 221-230. doi:10.1007/s40139-016-0114-6

Lafargue, A., Degorre, C., Corre, I., Alves-Guerra, M.-C., Gaugler, M.-H., Vallette, F., et al. (2017). Ionizing Radiation Induces Long-Term Senescence in Endothelial Cells through Mitochondrial Respiratory Complex II Dysfunction and Superoxide Generation. Free Radic. Biol. Med. 108, 750-759. doi:10.1016/j.freeradbiomed.2017.04.019 
Leavitt, R. J., Limoli, C. L., and Baulch, J. E. (2019). miRNA-Based Therapeutic Potential of Stem Cell-Derived Extracellular Vesicles: a Safe Cell-free Treatment to Ameliorate Radiation-Induced Brain Injury. Int. J. Radiat. Biol. 95 (4), 427-435. doi:10.1080/09553002.2018.1522012

Lee, C., Mitsialis, S. A., Aslam, M., Vitali, S. H., Vergadi, E., Konstantinou, G., et al. (2012). Exosomes Mediate the Cytoprotective Action of Mesenchymal Stromal Cells on Hypoxia-Induced Pulmonary Hypertension. Circulation 126 (22), 2601-2611. doi:10.1161/CIRCULATIONAHA.112.114173

Lee, S., Lee, S.-J., and Yoon, Y.-s. (2019). Vascular Regeneration with New Sources of Endothelial Cells. Circ. Res. 124 (1), 29-31. doi:10.1161/circresaha.118. 314195

Lei, X., He, N., Zhu, L., Zhou, M., Zhang, K., Wang, C., et al. (2020). Mesenchymal Stem Cell-Derived Extracellular Vesicles Attenuate Radiation-Induced Lung Injury via miRNA-214-3p. Antioxid. Redox Signaling. doi:10.1089/ars.2019. 7965

Letsiou, E., and Bauer, N. (2018). Endothelial Extracellular Vesicles in Pulmonary Function and Disease. Curr. Top. Membr. 82, 197-256. doi:10.1016/bs.ctm. 2018.09.002

Letsiou, E., Sammani, S., Zhang, W., Zhou, T., Quijada, H., Moreno-Vinasco, L., et al. (2015). Pathologic Mechanical Stress and Endotoxin Exposure Increases Lung Endothelial Microparticle Shedding. Am. J. Respir. Cel Mol Biol 52 (2), 193-204. doi:10.1165/rcmb.2013-03470C

Li, M., Wang, T., Tian, H., Wei, G., Zhao, L., and Shi, Y. (2019). Macrophagederived Exosomes Accelerate Wound Healing through Their Antiinflammation Effects in a Diabetic Rat Model. Artif. Cell Nanomedicine, Biotechnol. 47 (1), 3793-3803. doi:10.1080/21691401.2019.1669617

Li, M., You, L., Xue, J., and Lu, Y. (2018). Ionizing Radiation-Induced Cellular Senescence in Normal, Non-transformed Cells and the Involved DNA Damage Response: A Mini Review. Front. Pharmacol. 9, 522. doi:10.3389/fphar.2018. 00522

Li, T., Yan, Y., Wang, B., Qian, H., Zhang, X., Shen, L., et al. (2013). Exosomes Derived from Human Umbilical Cord Mesenchymal Stem Cells Alleviate Liver Fibrosis. Stem Cell Development 22 (6), 845-854. doi:10.1089/scd.2012.0395

Liao, H., Wang, H., Rong, X., Li, E., Xu, R.-H., and Peng, Y. (2017). Mesenchymal Stem Cells Attenuate Radiation-Induced Brain Injury by Inhibiting Microglia Pyroptosis. Biomed. Res. Int. 2017, 1-11. doi:10.1155/2017/1948985

Lim, J.-Y., Ra, J. C., Shin, I. S., Jang, Y. H., An, H.-Y., Choi, J.-S., et al. (2013). Systemic Transplantation of Human Adipose Tissue-Derived Mesenchymal Stem Cells for the Regeneration of Irradiation-Induced Salivary Gland Damage. PLoS One 8 (8), e71167. doi:10.1371/journal.pone.0071167

Lin, S.-L., Li, B., Rao, S., Yeo, E.-J., Hudson, T. E., Nowlin, B. T., et al. (2010). Macrophage Wnt7b Is Critical for Kidney Repair and Regeneration. Proc. Natl. Acad. Sci. 107 (9), 4194-4199. doi:10.1073/pnas.0912228107

Lötvall, J., Hill, A. F., Hochberg, F., Buzás, E. I., Di Vizio, D., Gardiner, C., et al. (2014). Minimal Experimental Requirements for Definition of Extracellular Vesicles and Their Functions: a Position Statement from the International Society for Extracellular Vesicles. J. Extracellular Vesicles 3, 26913. doi:10.3402/jev.v3.26913

Lou, G., Chen, Z., Zheng, M., and Liu, Y. (2017). Mesenchymal Stem Cell-Derived Exosomes as a New Therapeutic Strategy for Liver Diseases. Exp. Mol. Med. 49 (6), e346. doi:10.1038/emm.2017.63

Luan, X., Sansanaphongpricha, K., Myers, I., Chen, H., Yuan, H., and Sun, D. (2017). Engineering Exosomes as Refined Biological Nanoplatforms for Drug Delivery. Acta Pharmacol. Sin 38 (6), 754-763. doi:10.1038/aps.2017.12

Luo, W., Dai, Y., Chen, Z., Yue, X., Andrade-Powell, K. C., and Chang, J. (2020). Spatial and Temporal Tracking of Cardiac Exosomes in Mouse Using a NanoLuciferase-CD63 Fusion Protein. Commun. Biol. 3 (1), 114. doi:10.1038/ s42003-020-0830-7

Maimets, M., Rocchi, C., Bron, R., Pringle, S., Kuipers, J., Giepmans, B. N. G., et al. (2016). Long-Term In Vitro Expansion of Salivary Gland Stem Cells Driven by Wnt Signals. Stem Cel Rep. 6 (1), 150-162. doi:10.1016/j.stemcr.2015.11.009

Mandel, E. R., Uchida, C., Nwadozi, E., Makki, A., and Haas, T. L. (2017). Tissue Inhibitor of Metalloproteinase 1 Influences Vascular Adaptations to Chronic Alterations in Blood Flow. J. Cel. Physiol. 232 (4), 831-841. doi:10.1002/jcp.25491

Mantovani, A., Biswas, S. K., Galdiero, M. R., Sica, A., and Locati, M. (2013). Macrophage Plasticity and Polarization in Tissue Repair and Remodelling. J. Pathol. 229 (2), 176-185. doi:10.1002/path.4133

McBride, J. D., Rodriguez-Menocal, L., Guzman, W., Candanedo, A., GarciaContreras, M., and Badiavas, E. V. (2017). Bone Marrow Mesenchymal Stem
Cell-Derived CD63+ Exosomes Transport Wnt3a Exteriorly and Enhance Dermal Fibroblast Proliferation, Migration, and Angiogenesis In Vitro. Stem Cell Development 26 (19), 1384-1398. doi:10.1089/scd.2017.0087

Mead, B., and Tomarev, S. (2017). Bone Marrow-Derived Mesenchymal Stem Cells-Derived Exosomes Promote Survival of Retinal Ganglion Cells through miRNA-dependent Mechanisms. STEM CELLS Translational Med. 6 (4), 1273-1285. doi:10.1002/sctm.16-0428

Melgar-Lesmes, P., Balcells, M., and Edelman, E. R. (2017). Implantation of Healthy Matrix-Embedded Endothelial Cells Rescues Dysfunctional Endothelium and Ischaemic Tissue in Liver Engraftment. Gut 66 (7), 1297-1305. doi:10.1136/gutjnl-2015-310409

Mendelson, A., and Frenette, P. S. (2014). Hematopoietic Stem Cell Niche Maintenance during Homeostasis and Regeneration. Nat. Med. 20 (8), 833-846. doi:10.1038/nm.3647

Misawa, T., Tanaka, Y., Okada, R., and Takahashi, A. (2020). Biology of Extracellular Vesicles Secreted from Senescent Cells as Senescenceassociated Secretory Phenotype Factors. Geriatr. Gerontol. Int. 20 (6), 539-546. doi:10.1111/ggi.13928

Moll, G., Ankrum, J. A., Kamhieh-Milz, J., Bieback, K., Ringdén, O., Volk, H.-D., et al. (2019). Intravascular Mesenchymal Stromal/Stem Cell Therapy Product Diversification: Time for New Clinical Guidelines. Trends Mol. Med. 25 (2), 149-163. doi:10.1016/j.molmed.2018.12.006

Nanduri, L. S. Y., Baanstra, M., Faber, H., Rocchi, C., Zwart, E., de Haan, G., et al. (2014). Purification and Ex Vivo Expansion of Fully Functional Salivary Gland Stem Cells. Stem Cel Rep. 3 (6), 957-964. doi:10.1016/j.stemcr.2014.09.015

Nicolay, N. H., Lopez Perez, R., Saffrich, R., and Huber, P. E. (2015). Radio-resistant mesenchymal stem cells: mechanisms of resistance and potential implications for the clinic. Oncotarget 6 (23), 19366-19380. doi:10.18632/oncotarget.4358

Nolta, J. A., Galipeau, J., and Phinney, D. G. (2020). Improving Mesenchymal Stem/stromal Cell Potency and Survival. Cytotherapy 22 (3), 123-126. doi:10. 1016/j.jcyt.2020.01.004

Orfanos, S. E., Mavrommati, I., Korovesi, I., and Roussos, C. (2004). Pulmonary Endothelium in Acute Lung Injury: from Basic Science to the Critically Ill. Intensive Care Med. 30 (9), 1702-1714. doi:10.1007/s00134-004-2370-x

Pacheco, R., and Stock, H. (2013). Effects of Radiation on Bone. Curr. Osteoporos. Rep. 11 (4), 299-304. doi:10.1007/s11914-013-0174-z

Panganiban, R. A. M., Mungunsukh, O., and Day, R. M. (2012). X-irradiation Induces ER Stress, Apoptosis, and Senescence in Pulmonary Artery Endothelial Cells. Int. J. Radiat. Biol. 89 (8), 656-667. doi:10.3109/09553002.2012.711502

Paris, F., Fuks, Z., Kang, A., Capodieci, P., Juan, G., Ehleiter, D., et al. (2001). Endothelial Apoptosis as the Primary Lesion Initiating Intestinal Radiation Damage in Mice. Science 293 (5528), 293-297. doi:10.1126/science.1060191

Peña, L. A., Fuks, Z., and Kolesnick, R. N. (2000). Radiation-induced Apoptosis of Endothelial Cells in the Murine Central Nervous System: Protection by Fibroblast Growth Factor and Sphingomyelinase Deficiency. Cancer Res. 60 (2), 321-327.

Peng, X., Wu, Y., Brouwer, U., van Vliet, T., Wang, B., Demaria, M., et al. (2020). Cellular Senescence Contributes to Radiation-Induced Hyposalivation by Affecting the Stem/progenitor Cell Niche. Cel Death Dis. 11 (10), 854. doi:10.1038/s41419-020-03074-9

Phinney, D. G., and Pittenger, M. F. (2017). Concise Review: MSC-Derived Exosomes for Cell-free Therapy. Stem Cells 35 (4), 851-858. doi:10.1002/ stem. 2575

Piryani, S. O., Jiao, Y., Kam, A. Y. F., Liu, Y., Vo-Dinh, T., Chen, B. J., et al. (2019). Endothelial Cell-Derived Extracellular Vesicles Mitigate Radiation-Induced Hematopoietic Injury. Int. J. Radiat. Oncolog ${ }^{*}$ Biology ${ }^{*}$ Physics 104 (2), 291-301. doi:10.1016/j.ijrobp.2019.02.008

Pull, S. L., Doherty, J. M., Mills, J. C., Gordon, J. I., and Stappenbeck, T. S. (2005). Activated Macrophages Are an Adaptive Element of the Colonic Epithelial Progenitor Niche Necessary for Regenerative Responses to Injury. Proc. Natl. Acad. Sci. 102 (1), 99-104. doi:10.1073/pnas.0405979102

Rafii, S., Butler, J. M., and Ding, B.-S. (2016). Angiocrine Functions of Organspecific Endothelial Cells. Nature 529 (7586), 316-325. doi:10.1038/ nature 17040

Rager, T. M., Olson, J. K., Zhou, Y., Wang, Y., and Besner, G. E. (2016). Exosomes Secreted from Bone Marrow-Derived Mesenchymal Stem Cells Protect the Intestines from Experimental Necrotizing Enterocolitis. J. Pediatr. Surg. 51 (6), 942-947. doi:10.1016/j.jpedsurg.2016.02.061 
Rajendran, R. L., Gangadaran, P., Seo, C. H., Kwack, M. H., Oh, J. M., Lee, H. W., et al. (2020). Macrophage-Derived Extracellular Vesicle Promotes Hair Growth. Cells 9 (4), 856. doi:10.3390/cells9040856

Rana, S., Yue, S., Stadel, D., and Zöller, M. (2012). Toward Tailored Exosomes: the Exosomal Tetraspanin Web Contributes to Target Cell Selection. Int. J. Biochem. Cel Biol. 44 (9), 1574-1584. doi:10.1016/j.biocel.2012.06.018

Riccobono, D., Agay, D., Scherthan, H., Forcheron, F., Vivier, M., Ballester, B., et al. (2012). Application of Adipocyte-Derived Stem Cells in Treatment of Cutaneous Radiation Syndrome. Health Phys. 103 (2), 120-126. doi:10.1097/ HP.0b013e318240595b

Rios, C., Jourdain, J.-R., and DiCarlo, A. L. (2017). Cellular Therapies for Treatment of Radiation Injury after a Mass Casualty Incident. Radiat. Res. 188 (2), 242-245. doi:10.1667/RR14835.1

Rocchi, C., and Emmerson, E. (2020). Mouth-Watering Results: Clinical Need, Current Approaches, and Future Directions for Salivary Gland Regeneration. Trends Mol. Med. 26 (7), 649-669. doi:10.1016/j.molmed.2020.03.009

Rong, X., Liu, J., Yao, X., Jiang, T., Wang, Y., and Xie, F. (2019). Human Bone Marrow Mesenchymal Stem Cells-Derived Exosomes Alleviate Liver Fibrosis through the Wnt/ $\beta$-Catenin Pathway. Stem Cel Res Ther. 10 (1), 98. doi:10. 1186/s13287-019-1204-2

Rotolo, J., Stancevic, B., Zhang, J., Hua, G., Fuller, J., Yin, X., et al. (2012). Anticeramide Antibody Prevents the Radiation Gastrointestinal Syndrome in Mice. J. Clin. Invest. 122 (5), 1786-1790. doi:10.1172/JCI59920

Royo, F., Théry, C., Falcón-Pérez, J. M., Nieuwland, R., and Witwer, K. W. (2020). Methods for Separation and Characterization of Extracellular Vesicles: Results of a Worldwide Survey Performed by the ISEV Rigor and Standardization Subcommittee. Cells 9 (9), 1955. doi:10.3390/cells9091955

Rühle, A., Xia, O., Perez, R. L., Trinh, T., Richter, W., Sarnowska, A., et al. (2018). The Radiation Resistance of Human Multipotent Mesenchymal Stromal Cells Is Independent of Their Tissue of Origin. Int. J. Radiat. Oncology ${ }^{*}$ Biology ${ }^{*}$ Physics 100 (5), 1259-1269. doi:10.1016/j.jirobp.2018.01.015

Sáez, T., de Vos, P., Kuipers, J., Sobrevia, L., and Faas, M. M. (2019). Exosomes Derived from Monocytes and from Endothelial Cells Mediate Monocyte and Endothelial Cell Activation under High D-Glucose Conditions. Immunobiology 224 (2), 325-333. doi:10.1016/j.imbio.2019.02.004

Sáez, T., de Vos, P., Kuipers, J., Sobrevia, L., and Faas, M. M. (2018). Fetoplacental Endothelial Exosomes Modulate High D -Glucose-Induced Endothelial Dysfunction. Placenta 66, 26-35. doi:10.1016/j.placenta.2018.04.010

Saha, S., Aranda, E., Hayakawa, Y., Bhanja, P., Atay, S., Brodin, N. P., et al. (2016). Macrophage-derived Extracellular Vesicle-Packaged WNTs Rescue Intestinal Stem Cells and Enhance Survival after Radiation Injury. Nat. Commun. 7, 13096. doi:10.1038/ncomms 13096

Saha, S., Bhanja, P., Kabarriti, R., Liu, L., Alfieri, A. A., and Guha, C. (2011). Bone Marrow Stromal Cell Transplantation Mitigates Radiation-Induced Gastrointestinal Syndrome in Mice. PLoS One 6 (9), e24072. doi:10.1371/ journal.pone.0024072

Schubart, A., Anderson, K., Mainolfi, N., Sellner, H., Ehara, T., Adams, C. M., et al. (2019). Small-molecule Factor B Inhibitor for the Treatment of ComplementMediated Diseases. Proc. Natl. Acad. Sci. USA 116 (16), 7926-7931. doi:10. 1073/pnas.1820892116

Singh, V., Fatanmi, O., Santiago, P., Simas, M., Hanlon, B., Garcia, M., et al. (2018). Current Status of Radiation Countermeasures for Acute Radiation Syndrome under Advanced Development. J. Radiat. Cancer Res. 9 (1), 13. doi:10.4103/jrcr. jrcr_3_18

Singh, S., Kloss, F. R., Brunauer, R., Schimke, M., Jamnig, A., Greiderer-Kleinlercher, B., et al. (2012). Mesenchymal stem cells show radioresistance in vivo. J. Cell. Mol. Med. 16 (4), 877-887. doi:10.1111/j.1582-4934.2011.01383.x

Singh, V. K., and Seed, T. M. (2020). BIO 300: a Promising Radiation Countermeasure under Advanced Development for Acute Radiation Syndrome and the Delayed Effects of Acute Radiation Exposure. Expert Opin. Investig. Drugs 29 (5), 429-441. doi:10.1080/13543784.2020.1757648

Soria, B., Martin-Montalvo, A., Aguilera, Y., Mellado-Damas, N., López-Beas, J., Herrera-Herrera, I., et al. (2019). Human Mesenchymal Stem Cells Prevent Neurological Complications of Radiotherapy. Front. Cel. Neurosci. 13, 204. doi:10.3389/fncel.2019.00204

Stevens, T., Phan, S., Frid, M. G., Alvarez, D., Herzog, E., and Stenmark, K. R. (2008). Lung Vascular Cell Heterogeneity: Endothelium, Smooth Muscle, and
Fibroblasts. Proc. Am. Thorac. Soc. 5 (7), 783-791. doi:10.1513/pats.200803027HR

Stewart, F. A., Seemann, I., Hoving, S., and Russell, N. S. (2013). Understanding Radiation-Induced Cardiovascular Damage and Strategies for Intervention. Clin. Oncol. 25 (10), 617-624. doi:10.1016/j.clon.2013.06.012

Taheri, B., Soleimani, M., Fekri Aval, S., Esmaeili, E., Bazi, Z., and Zarghami, N. (2019). Induced Pluripotent Stem Cell-derived Extracellular Vesicles: A Novel Approach for Cell-free Regenerative Medicine. J. Cel Physiol 234 (6), 8455-8464. doi:10.1002/jcp.27775

Takeuchi, R., Katagiri, W., Endo, S., and Kobayashi, T. (2019). Exosomes from Conditioned Media of Bone Marrow-Derived Mesenchymal Stem Cells Promote Bone Regeneration by Enhancing Angiogenesis. PLoS One 14 (11), e0225472. doi:10.1371/journal.pone.0225472

Tan, C., Lai, R., Wong, W., Dan, Y., Lim, S.-K., and Ho, H. (2014). Mesenchymal Stem Cell-Derived Exosomes Promote Hepatic Regeneration in DrugInduced Liver Injury Models. Stem Cel Res. Ther. 5 (3), 76. doi:10.1186/ scrt 465

Thery, C., Witwer, K. W., Aikawa, E., Alcaraz, M. J., Anderson, J. D., Andriantsitohaina, R., et al. (2018). Minimal Information for Studies of Extracellular Vesicles 2018 (MISEV2018): a Position Statement of the International Society for Extracellular Vesicles and Update of the MISEV2014 Guidelines. J. Extracell Vesicles 7 (1), 1535750. doi:10.1080/ 20013078.2018.1535750

Tomasoni, S., Longaretti, L., Rota, C., Morigi, M., Conti, S., Gotti, E., et al. (2013). Transfer of Growth Factor Receptor mRNA via Exosomes Unravels the Regenerative Effect of Mesenchymal Stem Cells. Stem Cell Development 22 (5), 772-780. doi:10.1089/scd.2012.0266

Tsiapalis, D., and O'Driscoll, L. (2020). Mesenchymal Stem Cell Derived Extracellular Vesicles for Tissue Engineering and Regenerative Medicine Applications. Cells 9 (4), 991. doi:10.3390/cells9040991

Uribe-Etxebarria, V., Luzuriaga, J., Luzuriaga, J., García-Gallastegui, P., Agliano, A., Unda, F., et al. (2017). Notch/Wnt Cross-Signalling Regulates Stemness of Dental Pulp Stem Cells through Expression of Neural Crest and Core Pluripotency Factors. eCM 34, 249-270. doi:10.22203/eCM.v034a16

Vakili, S., Ahooyi, T. M., Yarandi, S. S., Donadoni, M., Rappaport, J., and Sariyer, I. K. (2020). Molecular and Cellular Impact of Inflammatory Extracellular Vesicles (EVs) Derived from M1 and M2 Macrophages on Neural Action Potentials. Brain Sci. 10 (7), 424. doi:10.3390/brainsci10070424

van Balkom, B. W. M., Eisele, A. S., Pegtel, D. M., Bervoets, S., and Verhaar, M. C. (2015). Quantitative and Qualitative Analysis of Small RNAs in Human Endothelial Cells and Exosomes Provides Insights into Localized RNA Processing, Degradation and Sorting. J. Extracellular Vesicles 4, 26760. doi:10.3402/jev.v4.26760

Van Deun, J., Mestdagh, P., Mestdagh, P., Agostinis, P., Akay, Ö., Anand, S., et al. (2017). EV-TRACK: Transparent Reporting and Centralizing Knowledge in Extracellular Vesicle Research. Nat. Methods 14 (3), 228-232. doi:10.1038/ nmeth.4185

Viñas, J. L., Spence, M., Gutsol, A., Knoll, W., Burger, D., Zimpelmann, J., et al. (2018). Receptor-Ligand Interaction Mediates Targeting of Endothelial Colony Forming Cell-Derived Exosomes to the Kidney after Ischemic Injury. Sci. Rep. 8 (1), 16320. doi:10.1038/s41598-018-34557-7

Viswanathan, S., Shi, Y., Galipeau, J., Krampera, M., Leblanc, K., Martin, I., et al. (2019). Mesenchymal Stem versus Stromal Cells: International Society for Cell \& Gene Therapy (ISCT) Mesenchymal Stromal Cell Committee Position Statement on Nomenclature. Cytotherapy 21 (10), 1019-1024. doi:10.1016/j. jcyt.2019.08.002

Vrijsen, K. R., Maring, J. A., Chamuleau, S. A. J., Verhage, V., Mol, E. A., Deddens, J. C., et al. (2016). Exosomes from Cardiomyocyte Progenitor Cells and Mesenchymal Stem Cells Stimulate Angiogenesis via EMMPRIN. Adv. Healthc. Mater. 5 (19), 2555-2565. doi:10.1002/adhm.201600308

Walasek, M. A., van Os, R., and de Haan, G. (2012). Hematopoietic Stem Cell Expansion: Challenges and Opportunities. Ann. N. Y Acad. Sci. 1266, 138-150. doi:10.1111/j.1749-6632.2012.06549.x

Wallis, R., Mizen, H., and Bishop, C. L. (2020). The Bright and Dark Side of Extracellular Vesicles in the Senescence-Associated Secretory Phenotype. Mech. Ageing Development 189, 111263. doi:10.1016/j. mad.2020.111263 
Wang, H., Zheng, R., Chen, Q., Shao, J., Yu, J., and Hu, S. (2017). Mesenchymal Stem Cells Microvesicles Stabilize Endothelial Barrier Function Partly Mediated by Hepatocyte Growth Factor (HGF). Stem Cel Res Ther. 8 (1), 211. doi:10.1186/ s13287-017-0662-7

Wang, J., Boerma, M., Fu, Q., and HauerJensen, M. (2007). Significance of Endothelial Dysfunction in the Pathogenesis of Early and Delayed Radiation Enteropathy. Wjg 13 (22), 3047-3055. doi:10.3748/wjg.v13.i22.3047

Wang, L., Wei, J., Da Fonseca Ferreira, A., Wang, H., Zhang, L., Zhang, Q., et al. (2020). Rejuvenation of Senescent Endothelial Progenitor Cells by Extracellular Vesicles Derived from Mesenchymal Stromal Cells. JACC: Basic Translational Sci. 5 (11), 1127-1141. doi:10.1016/j.jacbts.2020.08.005

Wang, Y., Liu, L., and Zhou, D. (2011). Inhibition of P38 MAPK Attenuates Ionizing Radiation-Induced Hematopoietic Cell Senescence and Residual Bone Marrow Injury. Radiat. Res. 176 (6), 743-752. doi:10.1667/rr2727.1

Wang, Y., Xie, Y., Zhang, A., Wang, M., Fang, Z., and Zhang, J. (2019). Exosomes: An Emerging Factor in Atherosclerosis. Biomed. Pharmacother. 115, 108951. doi:10.1016/j.biopha.2019.108951

Wei, X., Yi, X., Lv, H., Sui, X., Lu, P., Li, L., et al. (2020). MicroRNA-377-3p Released by Mesenchymal Stem Cell Exosomes Ameliorates Lipopolysaccharide-Induced Acute Lung Injury by Targeting RPTOR to Induce Autophagy. Cel Death Dis. 11 (8), 657. doi:10.1038/s41419-020-02857-4

Wen, S., Dooner, M., Cheng, Y., Papa, E., Del Tatto, M., Pereira, M., et al. (2016). Mesenchymal Stromal Cell-Derived Extracellular Vesicles Rescue Radiation Damage to Murine Marrow Hematopoietic Cells. Leukemia 30 (11), 2221-2231. doi:10.1038/leu.2016.107

Wen, S., Dooner, M., Papa, E., Del Tatto, M., Pereira, M., Borgovan, T., et al. (2019). Biodistribution of Mesenchymal Stem Cell-Derived Extracellular Vesicles in a Radiation Injury Bone Marrow Murine Model. Ijms 20 (21), 5468. doi:10.3390/ ijms 20215468

Wiklander, O. P. B., Nordin, J. Z., O'Loughlin, A., Gustafsson, Y., Corso, G., Mäger, I., et al. (2015). Extracellular Vesicle In Vivo Biodistribution Is Determined by Cell Source, Route of Administration and Targeting. J. Extracellular Vesicles 4, 26316. doi:10.3402/jev.v4.26316

Witwer, K. W., Van Balkom, B. W. M., Bruno, S., Choo, A., Dominici, M., Gimona, M., et al. (2019). Defining Mesenchymal Stromal Cell (MSC)-derived Small Extracellular Vesicles for Therapeutic Applications. J. Extracellular Vesicles 8 (1), 1609206. doi:10.1080/20013078.2019.1609206

Wong, K. L., Zhang, S., Wang, M., Ren, X., Afizah, H., Lai, R. C., et al. (2020). IntraArticular Injections of Mesenchymal Stem Cell Exosomes and Hyaluronic Acid Improve Structural and Mechanical Properties of Repaired Cartilage in a Rabbit Model. Arthrosc. J. Arthroscopic Relat. Surg. 36 (8), 2215-2228. doi:10.1016/j. arthro.2020.03.031

Wong, P. F., Tong, K. L., Jamal, J., Khor, E. S., Lai, S. L., and Mustafa, M. R. (2019). Senescent HUVECs-Secreted Exosomes Trigger Endothelial Barrier Dysfunction in Young Endothelial Cells. EXCLI J. 18, 764-776. doi:10.17179/excli2019-1505

Wynn, T. A., Chawla, A., and Pollard, J. W. (2013). Macrophage Biology in Development, Homeostasis and Disease. Nature 496 (7446), 445-455. doi:10. 1038/nature12034

Xiao, B., Chai, Y., Lv, S., Ye, M., Wu, M., Xie, L., et al. (2017). Endothelial CellDerived Exosomes Protect SH-Sy5y Nerve Cells against Ischemia/reperfusion Injury. Int. J. Mol. Med. 40 (4), 1201-1209. doi:10.3892/ijmm.2017.3106

Xu, J., Yan, X., Gao, R., Mao, L., Cotrim, A. P., Zheng, C., et al. (2010). Effect of Irradiation on Microvascular Endothelial Cells of Parotid Glands in the Miniature Pig. Int. J. Radiat. Oncology ${ }^{\star}$ Biology ${ }^{\star}$ Physics 78 (3), 897-903. doi:10.1016/j.ijrobp.2010.05.048

Xu, R., Zhang, F., Chai, R., Zhou, W., Hu, M., Liu, B., et al. (2019a). Exosomes Derived from Pro-inflammatory Bone Marrow-derived Mesenchymal Stem Cells Reduce Inflammation and Myocardial Injury via Mediating Macrophage Polarization. J. Cel Mol Med 23 (11), 7617-7631. doi:10.1111/jcmm.14635

Xu, S., Liu, C., and Ji, H.-L. (2019b). Concise Review: Therapeutic Potential of the Mesenchymal Stem Cell Derived Secretome and Extracellular Vesicles for Radiation-Induced Lung Injury: Progress and Hypotheses. STEM CELLS Translational Med. 8 (4), 344-354. doi:10.1002/sctm.18-0038
Yan, K. S., Chia, L. A., Li, X., Ootani, A., Su, J., Lee, J. Y., et al. (2012). The Intestinal Stem Cell Markers Bmil and Lgr5 Identify Two Functionally Distinct Populations. Proc. Natl. Acad. Sci. 109 (2), 466-471. doi:10.1073/pnas. 1118857109

Yan, W., Li, T., Yin, T., Hou, Z., Qu, K., Wang, N., et al. (2020). M2 MacrophageDerived Exosomes Promote the C-KIT Phenotype of Vascular Smooth Muscle Cells during Vascular Tissue Repair after Intravascular Stent Implantation. Theranostics 10 (23), 10712-10728. doi:10.7150/thno.46143

Yang, R., Liao, Y., Wang, L., He, P., Hu, Y., Yuan, D., et al. (2019). Exosomes Derived from M2b Macrophages Attenuate DSS-Induced Colitis. Front. Immunol. 10, 2346. doi:10.3389/fimmu.2019.02346

Zhang, G., Zou, X., Huang, Y., Wang, F., Miao, S., Liu, G., et al. (2016). Mesenchymal Stromal Cell-Derived Extracellular Vesicles Protect against Acute Kidney Injury through Anti-oxidation by Enhancing Nrf2/ARE Activation in Rats. Kidney Blood Press. Res. 41 (2), 119-128. doi:10.1159/ 000443413

Zhang, L., Jiao, G., Ren, S., Zhang, X., Li, C., Wu, W., et al. (2020a). Exosomes from Bone Marrow Mesenchymal Stem Cells Enhance Fracture Healing through the Promotion of Osteogenesis and Angiogenesis in a Rat Model of Nonunion. Stem Cel Res Ther. 11 (1), 38. doi:10.1186/s13287-020-1562-9

Zhang, Y., Chopp, M., Meng, Y., Katakowski, M., Xin, H., Mahmood, A., et al. (2015). Effect of Exosomes Derived from Multipluripotent Mesenchymal Stromal Cells on Functional Recovery and Neurovascular Plasticity in Rats after Traumatic Brain Injury. Jns 122 (4), 856-867. doi:10.3171/2014.11. JNS14770

Zhang, Y., Jiang, X., and Ren, L. (2019). Optimization of the Adipose-Derived Mesenchymal Stem Cell Delivery Time for Radiation-Induced Lung Fibrosis Treatment in Rats. Sci. Rep. 9 (1), 5589. doi:10.1038/s41598-019-41576-5

Zhang, Y., Qin, Y., Chopp, M., Li, C., Kemper, A., Liu, X., et al. (2020b). Ischemic Cerebral Endothelial Cell-Derived Exosomes Promote Axonal Growth. Stroke 51 (12), 3701-3712. doi:10.1161/STROKEAHA.120.031728

Zheng, K., Wu, W., Yang, S., Huang, L., Chen, J., Gong, C., et al. (2016). Treatment of Radiation-Induced Acute Intestinal Injury with Bone Marrow-Derived Mesenchymal Stem Cells. Exp. Ther. Med. 11 (6), 2425-2431. doi:10.3892/ etm.2016.3248

Zhou, Y., Li, P., Goodwin, A. J., Cook, J. A., Halushka, P. V., Chang, E., et al. (2018). Exosomes from Endothelial Progenitor Cells Improve the Outcome of a Murine Model of Sepsis. Mol. Ther. 26 (5), 1375-1384. doi:10.1016/j.ymthe.2018.02.020

Ziegler, V., Henninger, C., Simiantonakis, I., Buchholzer, M., Ahmadian, M. R., Budach, W., et al. (2017). Rho Inhibition by Lovastatin Affects Apoptosis and DSB Repair of Primary Human Lung Cells In Vitro and Lung Tissue In Vivo Following Fractionated Irradiation. Cel Death Dis. 8 (8), e2978. doi:10.1038/ cddis. 2017.372

Zou, L., Ma, X., Lin, S., Wu, B., Chen, Y., and Peng, C. (2019). Bone Marrow Mesenchymal Stem Cell-derived E-xosomes P-rotect against M-yocardial I-nfarction by P-romoting A-utophagy. Exp. Ther. Med. 18 (4), 2574-2582. doi:10.3892/etm.2019.7874

Zuo, R., Liu, M., Wang, Y., Li, J., Wang, W., Wu, J., et al. (2019). BM-MSC-derived Exosomes Alleviate Radiation-Induced Bone Loss by Restoring the Function of Recipient BM-MSCs and Activating Wnt/ $\beta$-Catenin Signaling. Stem Cel Res Ther. 10 (1), 30. doi:10.1186/s13287-018-1121-9

Conflict of Interest: The authors declare that the research was conducted in the absence of any commercial or financial relationships that could be construed as a potential conflict of interest.

Copyright ( 2021 Nanduri, Duddempudi, Yang, Tamarat and Guha. This is an open-access article distributed under the terms of the Creative Commons Attribution License (CC BY). The use, distribution or reproduction in other forums is permitted, provided the original author(s) and the copyright owner(s) are credited and that the original publication in this journal is cited, in accordance with accepted academic practice. No use, distribution or reproduction is permitted which does not comply with these terms. 


\section{GLOSSARY}

ARS Acute radiation syndrome

BMASC Bone marrow-derived adherent stromal cell

BMMSC Bone marrow mesenchymal stem cells

BMM Bone marrow macrophage

BV/TV Bone volume fraction

CCL2 Chemokine (C-C motif) ligand 2

DAMP Damage-associated molecular patterns

DEARE Delayed effects of acute radiation exposure

DSB double-strand breaks

DSS Dextran sulfate sodium

EC Endothelial cell

EC-EVs Endothelial cell-extracellular vesicles

ECFC Endothelial colony-forming cells

ERK1/2 Extracellular signal-regulated protein kinase

EM Electron microscopy

EMMPRIN Extracellular matrix metalloproteinase inducer

EV Extracellular vesicle

FDA Food and drug administration

G-CSF Granulocyte colony-stimulating factor

GM-CSF Granulocyte-macrophage colony-stimulating factor

Gy unit of radiation

Gray $=100 \mathrm{rads}$

GMP Good manufacturing practice

HSCs Hematopoietic stem cells

HUVEC Human umbilical cord vein endothelial cells

ICAM1 Intercellular adhesion molecule 1
iPSC induced pluripotent stem cells

IL Interleukin

ISC Intestinal Stem Cells

ISEV International society of extracellular vesicles

Lgr5 Leucine-rich repeat-containing G-protein coupled receptor 5

MAPK Mitogen-activated protein kinase

Mфs Macrophages

MCM Medical countermeasure

MISEV Minimal information for studies on extracellular vesicles

MM6 Mono-Mac-6

MSC Mesenchymal Stem Cells

NF- $\mathbf{B}$ nuclear factor kappa-light-chain-enhancer of activated B cells

NIH National Institute of Health

PTEN Phosphatase and Tensin Homolog

RIBE Radiation-induced bystander effect

RILD Radiation-induced liver disease

ROS reactive oxygen species

SASP Senescence-associated secreted phenotype

SH-SY5Y human neuroblastoma cells

SOD Super oxide dismutase

SSB Single strand breaks

TCF/LEF T-cell factor/lymphoid enhancer factor

TNF- $\boldsymbol{\alpha}$ Tumor necrosis factor-alpha

TSG101 Tumor susceptibility gene 101

Plau/uPA urokinase-type plasminogen activator

VCAM1 Vascular cell adhesion molecule 1

VE-cadherin Vascular endothelial-cadherin

WBI Whole-body irradiation 